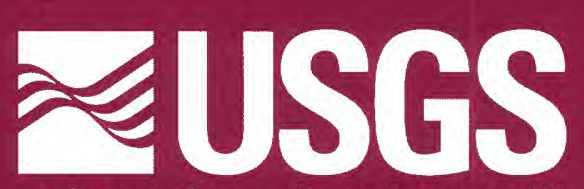

science for a changing world

Geochronology and Geology of

Late Oligocene Through Miocene

Volcanism and Mineralization in the

Western San Juan Mountains, Colorado

U.S. Geological Survey Professional Paper 1642 
Cover. View of outflow Fish Canyon Tuff (lower cliffs), near Lake City, Colo. 


\section{Geochronology and Geology of Late Oligocene Through Miocene Volcanism and Mineralization in the Western San Juan Mountains, Colorado}

By Dana J. Bove, Ken Hon, Karin E. Budding, John F. Slack, Lawrence W. Snee, and Ross A. Yeoman

U.S. Geological Survey Professional Paper 1642 


\section{U.S. Department of the Interior \\ Gale A. Norton, Secretary}

\section{U.S. Geological Survey \\ Charles G. Groat, Director}

Version 1.0

First printing 2001

For sale by U.S. Geological Survey, Information Services

Box 25286, Federal Center

Denver, CO 80225

This publication is also available online at:

http://geology.cr.usgs.gov/pub/ppapers/p1642

Any use of trade, product, or firm names in this publication

is for descriptive purposes only and

does not imply endorsement by the U.S. Government

\section{Library of Congress Cataloging-in-Publication Data}

Geochronology and geology of Late Oligocene through Miocene volcanism and mineralization in the western San Juan Mountains, Colorado / by Dana J. Bove ... [et al.]. p. cm. - (U.S. Geological Survey professional paper; 1642)

Includes bibliographical references.

1. Geology, Stratigraphic-Oligocene. 2. Geology, Stratigraphic-Miocene. 3. Geology-San Juan Mountains (Colo. and N.M.). 4. Geology-Colorado. 5. Volcanism-San Juan Mountains (Colo. and N.M.).

I. Bove, Dana. II. Series.

QE693.G46 2001

$551.75^{\prime} 097883-\mathrm{dc} 21$

2001018752

ISBN $=0-607-97486-9$ 


\section{Contents}

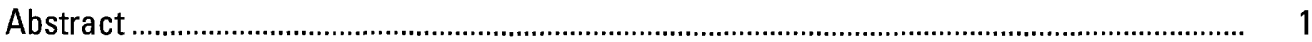

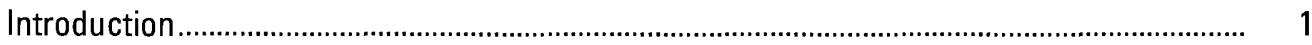

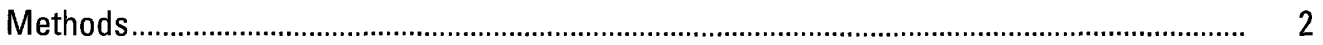

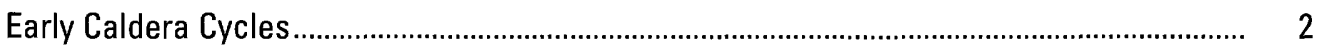

Geology and Previous Age-Related Studies ..................................................................... 2

New ${ }^{40} \mathrm{Ar} /{ }^{39} \mathrm{Ar}$ Ages and Interpretations........................................................................... 2

Regional 26-25 Ma Calc-Alkaline Intrusions............................................................................... 5

Geology and Previous Age-Related Studies ..................................................................... 5

New ${ }^{40} \mathrm{Ar}{ }^{39} \mathrm{Ar}$ Ages and Interpretations ........................................................................ 5

Veins and Porphyry-Style Alteration Related to 26-25 Ma Intrusions ...................................... 9

Geology and Previous Age-Related Studies .................................................................. 9

New ${ }^{40} \mathrm{Ar} /{ }^{\beta 9} \mathrm{Ar}$ Ages and Interpretations ....................................................................... 12

Evolution of the Lake City Caldera ........................................................................................ 12

Geology and Previous Age-Related Studies..................................................................... 12

New ${ }^{40} \mathrm{Ar} /{ }^{39} \mathrm{Ar}$ Ages and Interpretations ......................................................................... 14

Hydrothermal Activity and Mineralization Related to the Lake City Caldera ............................ 14

Geology and Previous Age-Related Studies .................................................................. 14

New ${ }^{40} \mathrm{Ar} /{ }^{39} \mathrm{Ar}$ Ages and Interpretations ...................................................................... 15

19-17 Ma Rhyolite Intrusions North and South of the Lake City Caldera and

Associated Mineralization .............................................................................................. 16

Discussion and Summary ...................................................................................................... 16

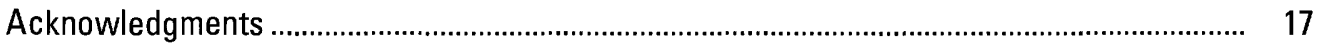

References Cited ............................................................................................................ 17

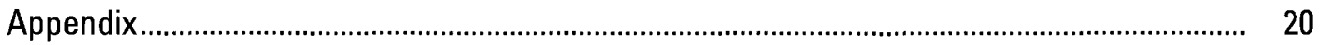

\section{Figures}

1. Map of the San Juan volcanic field, Colorado, showing location of

Oligocene calderas

2. Generalized geologic maps of western San Juan Mountains areas,

showing localities of dated samples

3. Diagrams showing ${ }^{40} \mathrm{Ar} /{ }^{39} \mathrm{Ar}$ age-spectra for dated samples .................................... $\quad 8$

4. Generalized geologic map of Lake City caldera ....................................................... 13

\section{Tables}

1. ${ }^{40} \mathrm{Ar} /{ }^{39} \mathrm{Ar}$ age-spectrum data for rocks and mineralized material from western San Juan Mountains.

2. Summary of new geochronologic data for western San Juan Mountains and previous K-Ar ages.

3. Sample descriptions and localities

4. ${ }^{40} \mathrm{Ar} /{ }^{39} \mathrm{Ar}$ data for mineral separates from rocks and mineralized material from western San Juan Mountains

5. K-Ar analytical data for rhyolitic rocks in Lake City area .......................................... 30 


\title{
Geochronology and Geology of Late Oligocene Through Miocene Volcanism and Mineralization in the Western San Juan Mountains, Colorado
}

\author{
By Dana J. Bove, Ken Hon, ${ }^{1}$ Karin E. Budding, ${ }^{2}$ John F. Slack, Lawrence W. Snee, \\ and Ross $\mathrm{A}$. Yeoman
}

Abstract

Twenty-five new ${ }^{40} \mathrm{Ar} /{ }^{39} \mathrm{Ar}$ ages from volcanic rocks and veins in the western San Juan Mountains clarify relationships between volcanism and mineralization in this classic area. Five calc-alkaline ash-flow sheets erupted from caldera sources (Ute Ridge, Blue Mesa, Dillon Mesa, Sapinero Mesa, and Crystal Lake Tuffs) from 28.6 to $27.6 \mathrm{Ma}$. This is a much more restricted time interval than previously thought and indicates that the underlying batholith rose and evolved very rapidly beneath the western San Juan Mountains. The new ages and geologic relations constrain the timing of joint resurgence of the Uncompahgre and San Juan calderas to between 28.2 and 27.6 Ma. The collapse of the Silverton caldera produced a set of strong ring fractures that intersected with graben faults on the earlier resurgent dome to produce the complex set of structures that localized the mid-Miocene epithermal gold veins.

Later calc-alkaline monzonitic to quartz monzonitic plutons solidified at $26.5-26.0 \mathrm{Ma}$ as the underlying batholith rose through its volcanic cover. A new age from lavas near Uncompahgre Peak supports earlier interpretations that these lavas were fed by nearby $26 \mathrm{Ma}$ monzonite intrusions. Nearly all of these intrusions are associated with subeconomic molybdenum and copper mineralization and associated alteration, and new ages of 26.40 and 25.29 Ma from the Ute-Ulay and Lilly veins in the Lake City region show that some of the most important silver and base-metal veins were temporally and possibly genetically connected to these plutons. In addition, the Golden Fleece telluride vein cuts all of the post-Uncompahgre caldera volcanics in the area and is probably temporally related to this cycle, though its age of $27.5 \pm 0.3$ Ma was determined by less precise $\mathrm{U} / \mathrm{Pb}$ methods.

The 22.9 Ma Lake City caldera collapsed within the older Uncompahgre caldera structure but is petrologically unrelated to the older calc-alkaline activity. The distinctive suite of highsilica rhyolite tuff and alkaline resurgent intrusions indicates that it is closely related to the early stages of bimodal high-silica rhyolite-alkali basalt volcanism that accompanied the onset of extensional tectonism in the region. Both ${ }^{40} \mathrm{Ar} /{ }^{39} \mathrm{Ar}$ ages and paleomagnetic data confirm that the entire caldera sequence formed in less than 330,000 years. Only weak quartz vein mineralization occurred in the center of the caldera, and it appears to be related to leaching of metals from the intracaldera tuffs above the resurgent intrusion. Massive alunitization and weak

\footnotetext{
1 University of Hawaii, Hilo, HI 96720.

${ }^{2} 150$ Green Rock Drive, Boulder, CO 80302.
}

molybdenum and copper mineralization along the eastern ring fracture are associated with calc-alkaline lavas and stocks related to late stages of the caldera cycle. These calc-alkaline stocks also appear to be genetically and temporally linked to a radial pattern of barite-precious-metal veins on the northeastern margin of the Lake City caldera.

\section{Introduction}

The rich epithermal vein and breccia pipe deposits of the western San Juan Mountains have been used as a model of the relationship between epithermal mineralization and volcanic activity for the past century (Ransome, 1901; Cross and Larsen, 1935; Varnes, 1963). During the past two decades, great advances have been made in understanding the style of calderarelated volcanism and its relationship to ore deposits in this classic area (Steven and Lipman, 1976). Though almost all of the mineralization is spatially related to the calderas that formed from 29 to $27 \mathrm{Ma}$, Lipman and others (1976) demonstrated that the large epithermal vein deposits are 10-15 Ma younger. The caldera-forming eruptions produced fractures and faults suitable for later mineralization but appear to have depleted the associated magmatic systems of any ore fluids capable of producing mineralization during the caldera cycle.

More recent studies by Slack (1980) identified base- and precious-metal veins that are mineralogically zoned and spatially distributed around the outside of the 23 Ma Lake City caldera. Although Slack proposed that these veins formed contemporaneously with the Lake City caldera, a U-Pb-isochron $(27.5 \pm 0.3 \mathrm{Ma})$ date on one of the richest of these veins indicates formation near the end of the earlier caldera cycle rather than during the Lake City caldera cycle (Hon and others, 1985). This in turn suggested the possibility of some mineralization in the western San Juan Mountains associated with the period of major caldera formation or the episode of calc-alkaline intrusive activity immediately following. However, massive alunitization and porphyry-style mineralization of postcollapse lavas within the Lake City caldera are undoubtedly contemporaneous with Lake City caldera formation and with similar acid-sulfate alteration and mineralization at Summitville and Red Mountain Pass (Bove and others, 1990; Gray and Coolbaugh, 1994; Gilzean, 1984).

Our goal was to obtain more precise ages from a variety of fresh and mineralized rocks to clarify key relationships between caldera formation and mineralization in the western San Juan Mountains. We have obtained a series of new ${ }^{40} \mathrm{Ar} /{ }^{39} \mathrm{Ar}$ ages from the main calc-alkaline ash-flow sheets and related younger calc-alkaline plutons, the ash-flows and lavas of the Lake City 
caldera cycle, and veins and other altered rocks in the Lake City region. Although these ages do not alter the general geological story of the western San Juan Mountains, they provide a much more precise chronological framework for interpreting durations of events and their relationship to mineralization. These ages are of similar quality to ${ }^{40} \mathrm{Ar} /{ }^{39} \mathrm{Ar}$ ages from the eastern and central San Juan Mountains (Lipman and others, 1997; Lanphere, 1988), making chronological interpretations between the regions more comparable. The detailed ages from the Lake City caldera and surrounding veins call for a further reevaluation of the timing of mineralization in this area and also allow testing of the paleomagnetic constraints on duration of the caldera cycle proposed by Reynolds and others (1986).

\section{Methods}

The ages of 25 mineral separates (see Appendix) were determined using the ${ }^{40} \mathrm{Ar} /{ }^{39} \mathrm{Ar}$ step-heating technique. With the exception of two sericite samples that were hand separated, samples were crushed and sieved to recover the 125 to $250 \mu \mathrm{m}$ fraction. The concentrates were washed in 10 percent $\mathrm{HCl}$ in an ultrasonic bath to remove carbonate and were hand picked to remove grains that showed evidence of incipient alteration. Samples were irradiated for about 30 hours at 1 megawatt in the U.S. Geological Survey TRIGA reactor in Denver. Corrections for radiation-produced interfering isotopes of argon were made by applying measured production ratios for the interfering isotopes of argon produced in pure $\mathrm{CaF}_{2}$ and $\mathrm{K}_{2} \mathrm{SO}_{4}$ irradiated along with the samples (see Appendix). Neutron flux during irradiation was monitored using hornblende standard MMhb-1, which has a K-Ar age of 520.4 $\pm 1.7 \mathrm{Ma}$ (Samson and Alexander, 1987). Errors of 0.1 percent in the calculated J-value were experimentally assessed by calculating the reproducibility of multiple monitors. Samples were heated in a low-background, resistively heated, double vacuum Ta-furnace in a series of eight to nineteen 20-minute-long steps. Isotopic abundances of argon were measured using a mass spectrometer operated in the static mode. All data were reduced using the decay constants and isotopic abundances suggested by Steiger and Jäger (1977). Age plateau criteria were based on Fleck and others (1977), whereby a plateau is defined by two or more contiguous gas fractions whose apparent ages are statistically indistinguishable at the 95 percent confidence level (Dalrymple and Lanphere, 1969) and which together total greater than 50 percent of the total ${ }^{39} \mathrm{Ar}_{\mathrm{K}}$ released. Plateau ages represent a weighted mean, where weighting is by the inverse of the analytical variance (Taylor, 1982). The error was determined using equations of Dalrymple and Lanphere (1981). For further details on this analytical method, see Snee and others (1988). All ages listed in this publication are reported at the $1 \sigma$ confidence level; previous $\mathrm{K}-\mathrm{Ar}$ ages have been recalculated using the 1977 IUGS constants (Hon and Mehnert, 1983).

\section{Early Caldera Cycles}

\section{Geology and Previous Age-Related Studies}

The Ute Ridge Tuff erupted from the Ute Creek caldera, the first of six calderas to form in the western San Juan caldera cluster (fig. 1) (Lipman and others, 1973). This initial eruption of mafic dacite was followed by eruption of the Blue Mesa Tuff, Dillon Mesa Tuff, Sapinero Mesa Tuff, and Crystal Lake Tuff, a series of nearly indistinguishable low-silica rhyolites. Each of these ash-flow eruptions produced calderas, though the Dillon Mesa and Sapinero Mesa Tuffs appear to have both erupted from the coalesced San Juan-Uncompahgre caldera structure (Lipman and others, 1973).

Earlier reported K-Ar dates for the Ute Ridge Tuff (29.1 Ma) and Fish Canyon Tuff (27.8 Ma; central San Juan caldera cluster), which overlie the Sapinero Mesa Tuff, suggested that the four early calderas of the western San Juan complex formed in rapid succession (Lipman and others, 1970). However, the age of the Ute Ridge Tuff was actually an average of two discordant $\mathrm{K}$-Ar ages $(30.1 \pm 0.6 \mathrm{Ma}$ and $28.1 \pm 0.5 \mathrm{Ma})$ on coexisting biotite and sanidine. These age discrepancies underscore some of the inherent uncertainties in the K-Ar technique, which make it unsuitable for more rigorous age comparative studies.

We have redated the Ute Ridge Tuff and provided the first published dates from the Blue Mesa, Dillon Mesa, and Sapinero Mesa Tuffs to further refine the duration of the caldera-forming intervals and the timing of individual eruptions. Although the age of the Crystal Lake Tuff is bracketed by the underlying 27.8 Ma Fish Canyon Tuff (Kunk and others, 1985) and the overlying 27.6 Ma Carpenter Ridge Tuff (Lanphere, 1988) from the central San Juan caldera cluster, we also dated it to test the concordancy of our ages. The timing of caldera-related events for both the eastern and central caldera clusters has recently been refined using precise ${ }^{40} \mathrm{Ar} /{ }^{39} \mathrm{Ar}$ dating (Lipman and others, 1997; Lanphere, 1988), and here we present similar ${ }^{40} \mathrm{Ar} /{ }^{\beta 9} \mathrm{Ar}$ data for the western San Juans, so that the timing of events can be more easily compared.

\section{New ${ }^{40} \mathrm{Ar} /{ }^{39} \mathrm{Ar}$ Ages and Interpretations}

Ten new ${ }^{40} \mathrm{Ar} /{ }^{39} \mathrm{Ar}$ age determinations were made on outflow pyroclastic units from early calderas ( $>23 \mathrm{Ma}$ ) of the western San Juan volcanic field (fig. $2 A, B$; table 1). Sanidine sample UR-1 from outcrops of Ute Ridge Tuff southwest of Finger Mesa (fig. $2 A$, loc. 1) has a slightly $U$-shaped spectrum (fig. $3 A$ ) suggesting the presence of minor excess ${ }^{40} \mathrm{Ar}$, but a weighted mean based on steps $4-9$, containing 57 percent of the ${ }^{39} \mathrm{Ar}_{\mathrm{K}}$ released, gives a weighted mean age $28.63 \mathrm{Ma}$ that we consider to best represent the age of this sample. This is confirmed by an ${ }^{40} \mathrm{Ar} /{ }^{36} \mathrm{Ar}$ vs. ${ }^{39} \mathrm{Ar} /{ }^{36} \mathrm{Ar}$ isochron plot (steps 2-12) with a slightly elevated atmospheric intercept $\left[\left({ }^{40} \mathrm{Ar} /{ }^{36} \mathrm{Ar}\right)_{\mathrm{i}}\right]$ of $316 \pm 5$, which is greater than the atmospheric value of 295.5 .

Sanidine (BM-2) from the Blue Mesa Tuff was obtained from a sequence of ash-flow tuffs on the north edge of Alpine Plateau (fig. $2 B$, loc. 2). This sample has a relatively simple age spectrum (fig. $3 B$ ) with a plateau age of $28.40 \pm 0.07 \mathrm{Ma}$. In contrast, the age spectrum for sanidine sample BM-3 from Blue Mesa Tuff east of Telluride (Potosi Peak; fig. $2 A$, loc. 3 ) is somewhat discordant, yielding a plateau age of $28.30 \pm 0.05 \mathrm{Ma}$; apparent ages within the spectrum show a gradual rise in the middle to higher temperature steps (fig. $3 C$ ). An isochron plot using all the steps gives an age of $28.59 \pm 0.2 \mathrm{Ma}$ with an atmospheric intercept $\left[\left({ }^{40} \mathrm{Ar} /{ }^{36} \mathrm{Ar}\right)_{i}\right]$ of $231 \pm 15$, indicating apparent argon loss. Although the isochron date is our best estimated age 


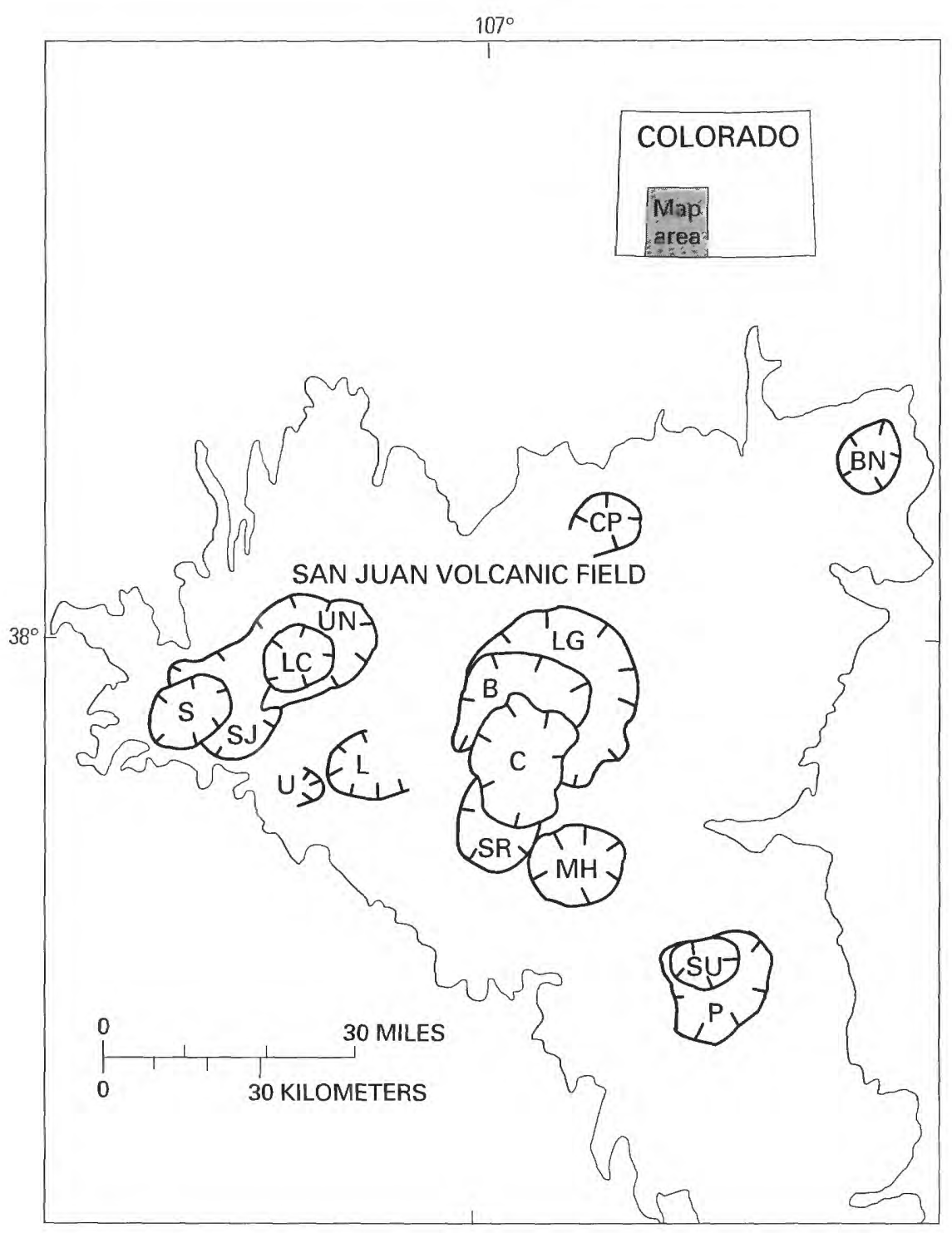

Figure 1. San Juan volcanic field, Colorado, showing location of Oligocene calderas (hachured lines). Calderas of western San Juan Mountains include U, Ute Creek; L, Lost Lake; UN, Uncompahgre; SJ, San Juan; S, Silverton; LC, Lake City. Calderas of central and eastern San Juan Mountains include LG, La Garita; B, Bachelor; C, Creede; SR, South River; MH, Mount Hope; CP, Cochetopa Park; SU, Summitville; P, Platoro; BN, Bonanza. Modified from Lipman and others (1997) and Lipman and Steven (1976).

for this sample, we use this age only to confirm the simple plateau age from sample BM-3 $(28.40 \pm 0.07 \mathrm{Ma})$, our preferred age for the Blue Mesa Tuff.

Sanidine from a single pumice (DM-3) collected from outcrops of Dillon Mesa Tuff on the south edge of Alpine Plateau (fig. $2 \mathrm{~B}$, loc. 4) gives an age spectrum that is slightly discordant (fig. $3 D$ ), but a weighted mean age using steps $3-9$ gives a preferred age mean of $28.38 \pm 0.05 \mathrm{Ma}$. Sanidine from Dillon Mesa Tuff at Potosi Peak (DM-4, loc. 5) has a simple age spectrum with a plateau age of $28.42 \pm 0.06 \mathrm{Ma}$ (fig. $3 E$ ). Our preferred age from sample DM-3 $(28.38 \pm 0.05 \mathrm{Ma})$ and the plateau age from sample DM-4 (28.42 $\pm 0.06 \mathrm{Ma})$ are analytically indistinguishable at the 95 percent confidence level and yield an arithmetic mean age of $28.40 \pm 0.04 \mathrm{Ma}$.

Three sanidine samples were analyzed from outflow of the Sapinero Mesa Tuff. The ${ }^{40} \mathrm{Ar} /{ }^{39} \mathrm{Ar}$ age spectra for all three samples are remarkably simple and easy to interpret. Sample
SM-4 (fig. $3 F$ ), collected from fiamme in vitrophyre near Gateway north of Lake City (fig. $2 B$, loc. 6), gave a plateau age of $28.22 \pm 0.07 \mathrm{Ma}$. Sample SM-5, which was collected from outcrops of the Sapinero Mesa Tuff southeast of Sapinero (fig. 2B, loc. 7), yielded a plateau age of $28.17 \pm 0.06 \mathrm{Ma}$ (fig. $3 G$ ). Finally, sample SM-6 from an ash-flow sequence near Potosi Peak (fig. $2 A$, loc. 8 ) gave a plateau date of $28.18 \pm 0.05 \mathrm{Ma}$ (fig. $3 H$ ). Data for all three samples overlap statistically at the 95 percent confidence level, yielding a weighted mean age of $28.19 \pm 0.03 \mathrm{Ma}$.

Sanidine sample CL-6 from a vitrophyre at the base of the Crystal Lake Tuff near Uncompahgre Peak (fig. $2 A$, loc. 9) has a simple age spectrum with a plateau age of $27.62 \pm 0.07 \mathrm{Ma}$ (fig. 3I). The age spectrum for sanidine sample CL-7 (fig. $3 J$ ) collected from Crystal Lake Tuff in South Clear Creek, near Hermit Lakes (fig. $2 A$, loc. 10), is somewhat discordant, although the intermediate steps of the age spectrum give a weighted mean age 


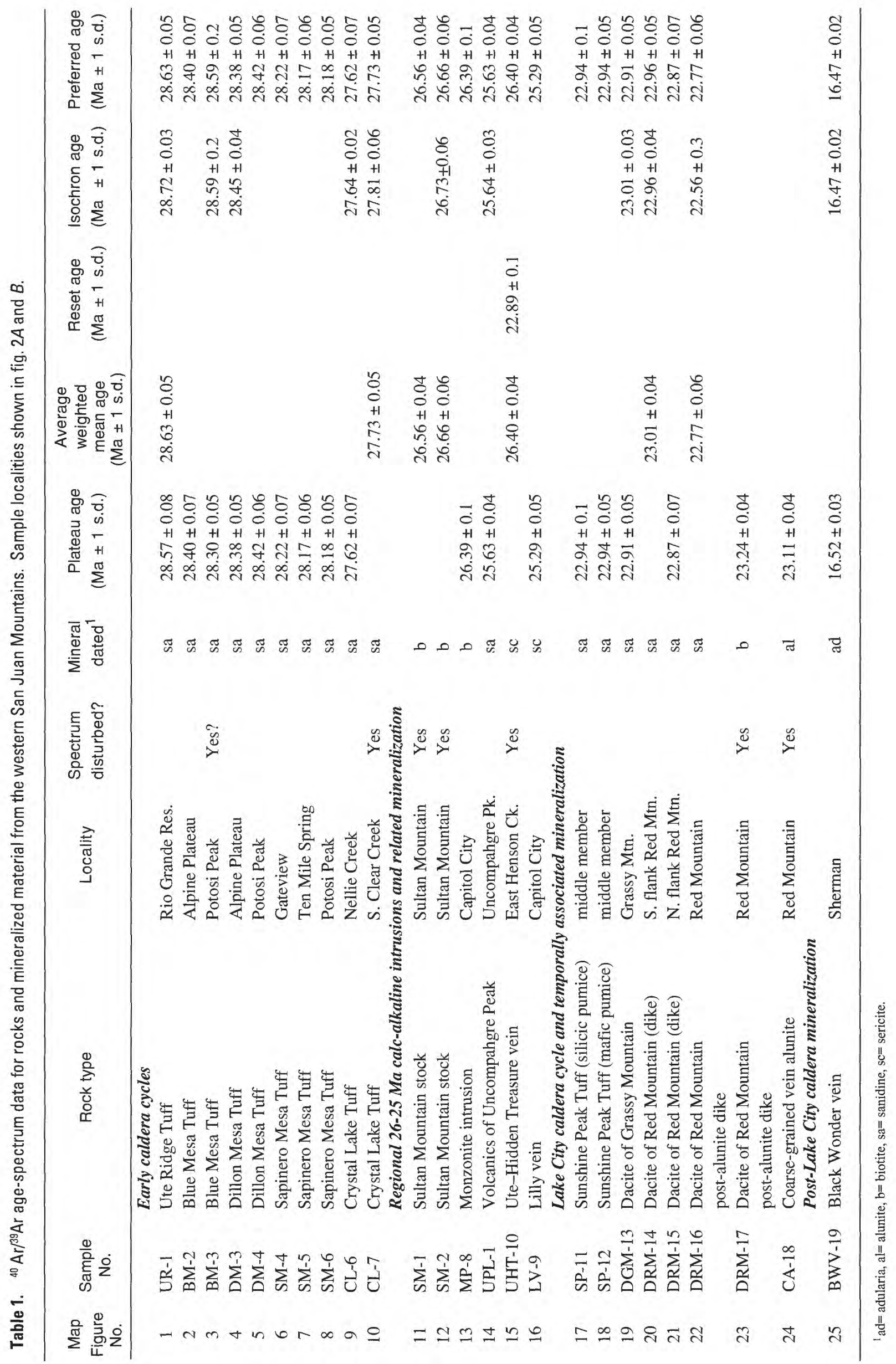


of $27.73 \pm 0.05 \mathrm{Ma}$ that probably represents a reasonable estimate of the age of this sample. However, given the complicated nature of this sample, we consider the date from the Nellie Creek sample CL-6 (27.62 $\pm 0.07 \mathrm{Ma})$ our preferred age of the Crystal Lake Tuff.

A summary of our new ${ }^{40} \mathrm{Ar} /{ }^{39} \mathrm{Ar}$ dates for the pyroclastic units of the western San Juan volcanic complex is presented in table 2. From these new data we can constrain early calderarelated volcanism in the western San Juan volcanic field to between 28.63 Ma (Ute Ridge Tuff) and 27.62 Ma (Crystal Lake Tuff) within a variance of 0.88 to 1.13 million years at the $1 \sigma$ confidence level. In addition, ${ }^{40} \mathrm{Ar} /{ }^{39} \mathrm{Ar}$ ages for the intervening Blue Mesa (28.40 $\pm 0.07 \mathrm{Ma})$, Dillon Mesa $(28.40 \pm 0.04)$ and Sapinero Mesa (28.19 $\pm 0.03 \mathrm{Ma}$ ) Tuffs record a very brief eruptive time interval ranging from 0.11 to 0.31 million years $(1 \sigma)$. The weighted mean or preferred ages of these units (table 2), with the exception of the Blue Mesa and Dillon Mesa Tuffs, are analytically distinguishable at the 95 percent confidence level using the Critical Value Test of Dalrymple and Lanphere (1969).

\section{Regional 26-25 Ma Calc-Alkaline Intrusions}

\section{Geology and Previous Age-Related Studies}

A large swarm of calc-alkaline intrusions was emplaced between 26 and 25 Ma over a broad region of the western San Juan Mountains. These intrusions range from large stocks at Mt. Wilson west of Ophir and Sultan Mountain near Silverton to smaller plugs intruded near Capitol City in the Lake City area (fig. 2A). Although the overall size of the exposed plutons decreases from west to east, this may be an artifact of erosion rather than a reflection of their actual size. These plutons vary from simple to complexly zoned and in many places are associated with veins and and disseminated and stockwork $\mathrm{Mo}-\mathrm{Cu}$ mineralized rocks (Ringrose and others, 1986; Slack, 1976; Caskey, 1979; Pyle, 1980). Many of these intrusions are completely crystalline and cut through the entire ash-flow sequence, suggesting that they may represent cores of now-eroded stratovolcanoes that fed thick sequences of lavas nearby (Lipman and others, 1973). Alternatively, the widespread distribution of intrusions also suggests that they represent the uppermost portion of the underlying batholith rising into and consuming the earlier volcanic pile-similar to the emplacement of the Boulder batholith into the Elkhorn Mountains Volcanics in Montana (Lipman, 1984).

Previous K-Ar determinations on biotite from the monzonitic Ophir and Sultan Mountain stocks (fig. $2 A$ ) gave concordant dates with a weighted mean age of $25.9 \pm 0.6 \mathrm{Ma}$ (Jackson and others, 1980). A weighted mean age of $25.2 \pm 0.6 \mathrm{Ma}$ (Jackson and others, 1980) was also determined from two concordant $\mathrm{K}$-Ar dates on biotite from slightly more evolved monzonite porphyry phases of the Sultan Mountain stock in the Middle ForkOphir Pass area near Silverton (fig. 2A) (Ringrose and others, 1986, fig. 1, p. 358). A K-Ar date of $25.7 \pm 0.6$ Ma was determined by H.H. Mehnert (in Slack, 1980) on biotite from one of several small monzonite to monzogranite porphyry stocks in the Capitol City area (fig. 2A). Like the nearby Capitol City stocks, small monzonite to dacite porphyry intrusions in the Iron Beds and Matterhorn Peak areas (fig. $2 A$ ) are also associated with zoned alteration and weak mineralization (Slack, 1976; Caskey, 1979; Pyle, 1980) and have K-Ar ages of $26.6 \pm 0.4$ (hornblende) and $25.2 \pm 2 \mathrm{Ma}$ (plagioclase), respectively (F. McDowell, written commun., 1994).

\section{New ${ }^{40} \mathrm{Ar} /{ }^{39} \mathrm{Ar}$ Ages and Interpretations}

Three biotite separates from samples related to the 26-25 Ma period of intrusion and mineralization were analyzed for this study (table 1). In addition, sanidine from the top of a thick sequence of lavas exposed near Uncompahgre Peak (fig. 2A) (volcanics of Uncompahgre Peak; Lipman, 1976) was dated to test the hypothesis of Lipman and others (1973) that these lavas were extrusive equivalents of the monzonite intrusions.

Two samples (SM-1 and SM-2) from the Sultan Mountain stock, near Silverton (fig. $2 A$, locs. 11,12 ) overlap at the 95 percent confidence level and have a weighted mean age of $26.60 \pm 0.04 \mathrm{Ma}$. Both samples have slight humps in the middle spectrum region that probably reflect the presence of incipiently chloritized biotite grains. Sample SM-1 has a weighted mean age of $26.56 \pm 0.04 \mathrm{Ma}$ (fig. $3 K$ ), whereas SM-2 has a weighted mean age of $26.66 \pm 0.06 \mathrm{Ma}$ (fig. $3 L$ ). Although both biotites gave disturbed age spectra, we consider a weighted mean date of $26.60 \pm 0.04 \mathrm{Ma}$ to be our best estimate of the cooling age of these samples.

Biotite MP-8 is from a monzonite intrusion near the Capitol City townsite, about $30 \mathrm{~km}$ northeast of Silverton (fig. $2 \mathrm{~A}$, loc. 13). This sample yields a simple age spectrum (fig. $3 M$ ) with a plateau age of $26.39 \pm 0.1 \mathrm{Ma}$, which represents the cooling age of this intrusion. Sanidine sample UPL-1 from dacitic lavas of the volcanics of Uncompahgre Peak (fig. $2 A$, loc. 14) yielded a simple age spectrum (fig. $3 N$ ) with a plateau age of $25.63 \pm 0.04 \mathrm{Ma}$.

The weighted mean age of $26.60 \pm 0.04 \mathrm{Ma}$ from Sultan Mountain stock biotite samples (SM-1, SM-2) is statistically indistinguishable from the plateau age $(26.39 \pm 0.1 \mathrm{Ma})$ of sample MP-8 from an intrusion in the Capitol City area (table 2).

Although these ages compare well to previous K-Ar determinations, late-phases of these intrusions such as documented in the Middle Fork-Ophir Pass area (25 Ma; Ringrose and others, 1986) are not represented in the present study. Still, these new ages show a minimum time break of about 1 million years between the end of early caldera-related magmatism in this area (27.6 Ma) and emplacement of these 26-25 Ma mineralized intrusions. The age of sanidine sample UPL-1 $(25.63 \pm 0.04 \mathrm{Ma})$ collected from the uppermost flows of the volcanics of

Figure 2 (following two pages). Generalized geologic maps of western San Juan Mountains area, showing localities of dated samples. Generalized caldera boundaries shown in figure 1. A, Geology modified from Lipman and others (1976) and Hon (1987b). B, North of the Lake City caldera. Geology modified from Tweto and others (1976). 


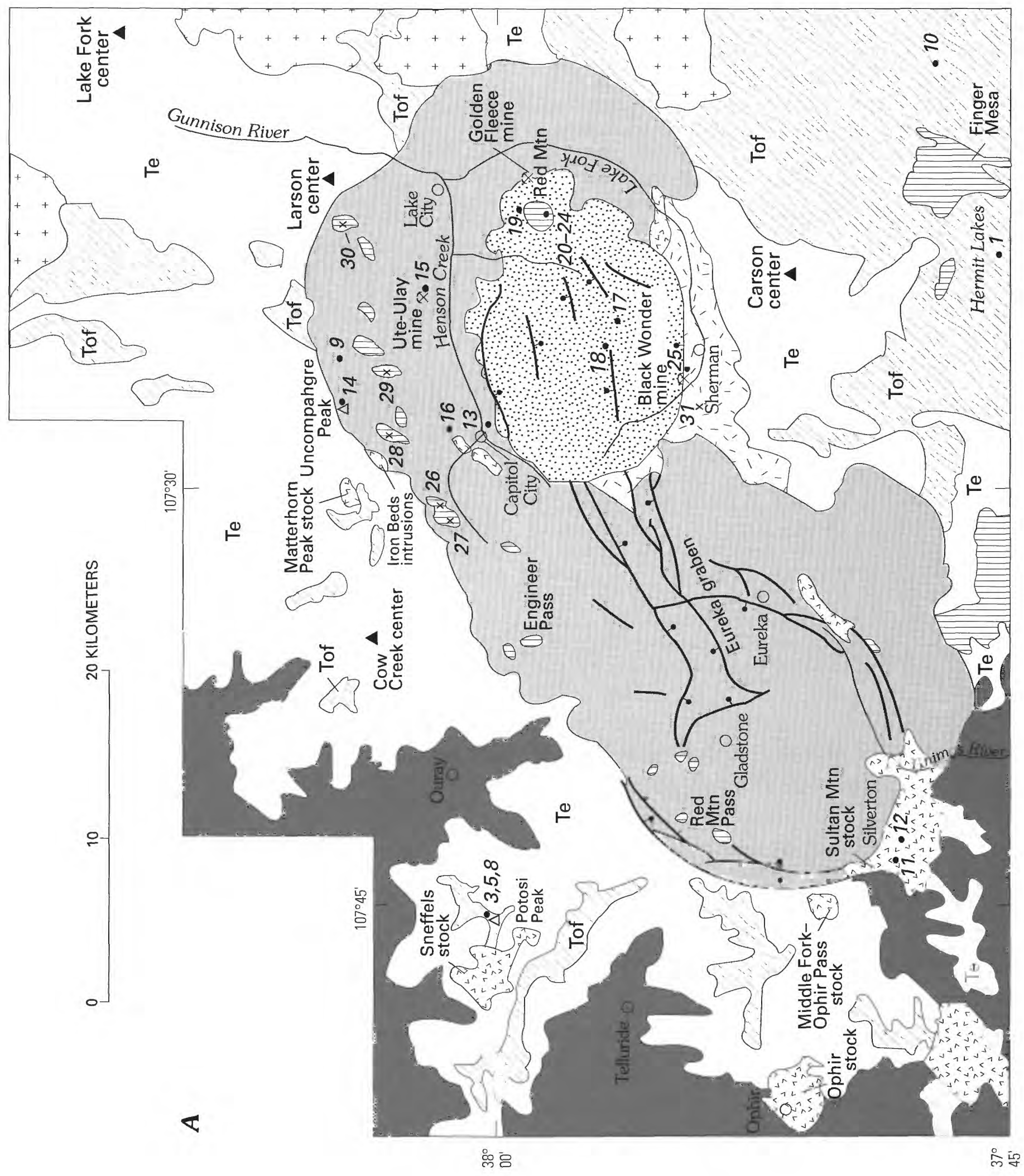




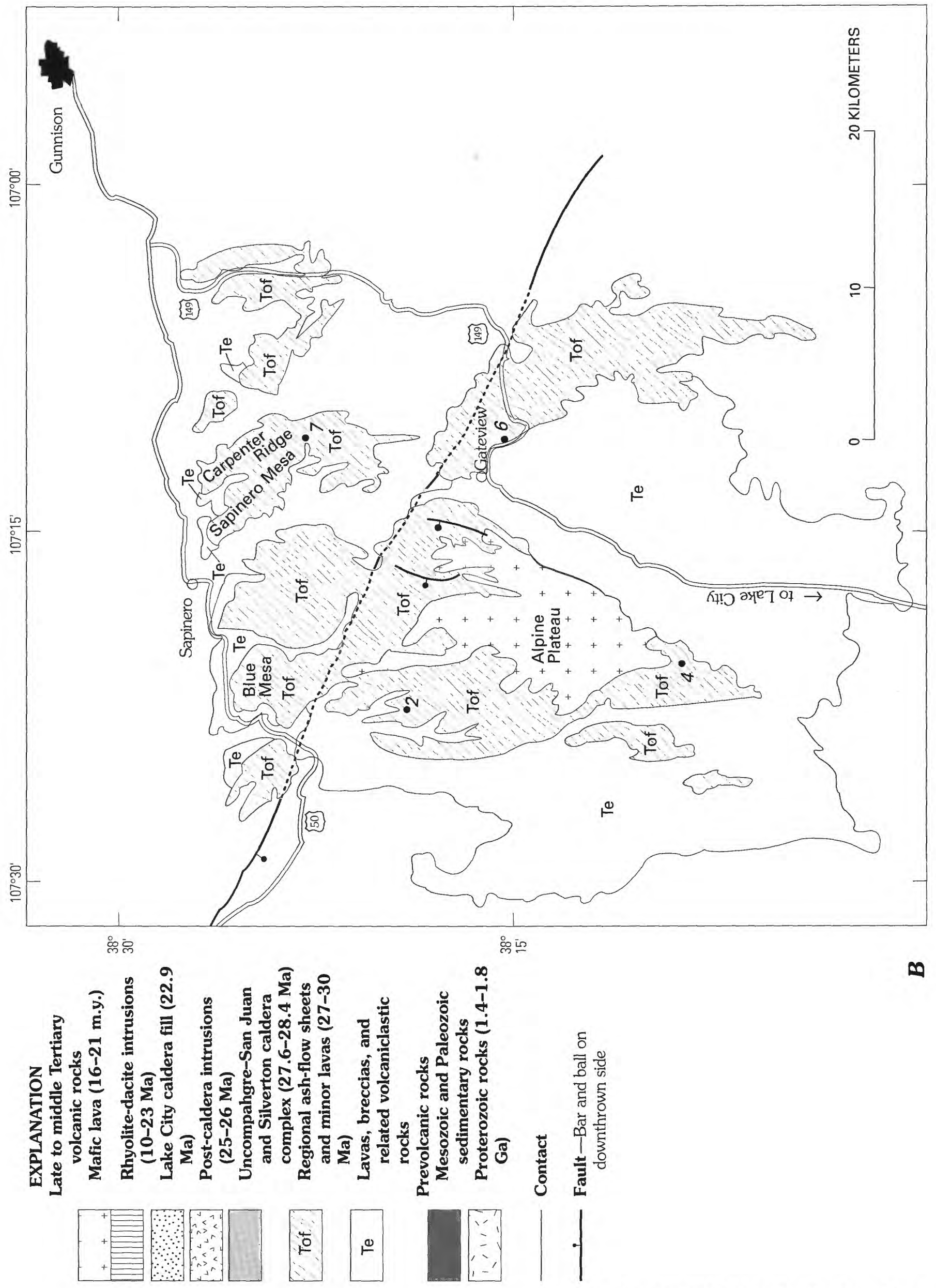



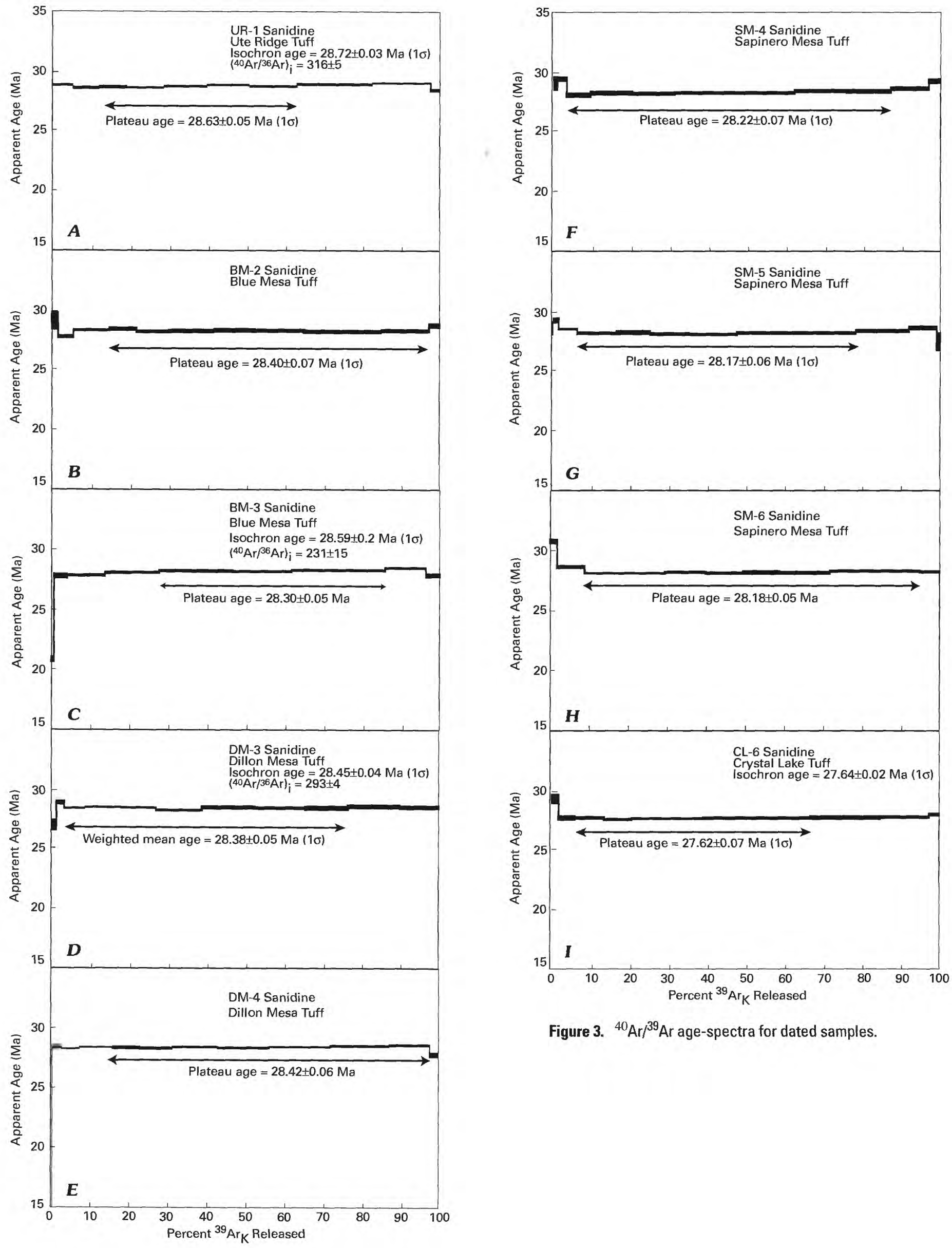

Figure 3. ${ }^{40} \mathrm{Ar} /{ }^{39} \mathrm{Ar}$ age-spectra for dated samples. 


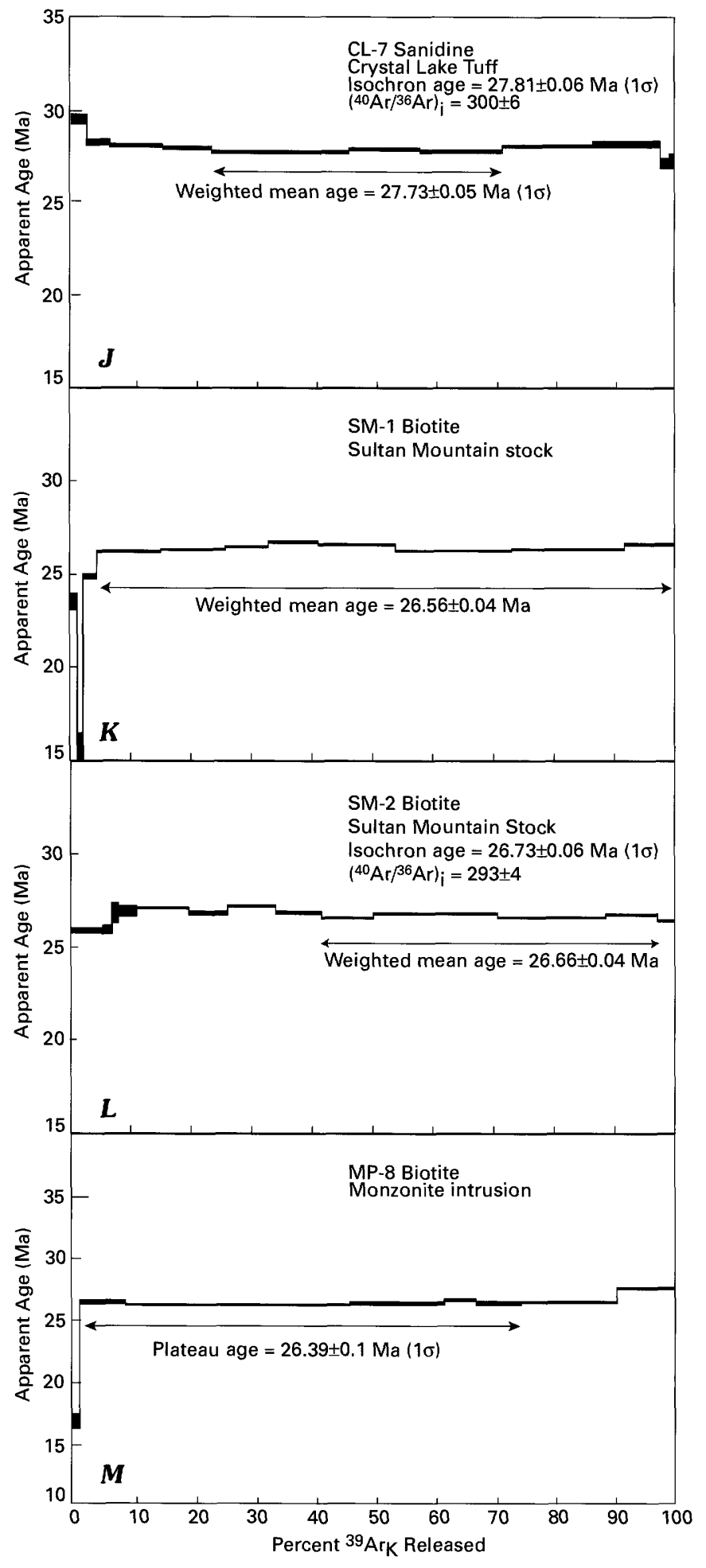

Figure 3-Continued. ${ }^{40} \mathrm{Ar} /{ }^{39} \mathrm{Ar}$ age-spectra for dated samples.

Uncompahgre Peak represents the minimum age of this thick sequence of dacitic to andesitic lavas. As this sample represents a minimum age for this thick sequence of flows, we consider it to be close enough in proximity to the 26.4 Ma date on the monzonite intrusion in Capitol City (table 2) to corroborate the assumption of Lipman and others (1973) that the Capitol City intrusions may have been the primary feeders for the volcanics of Uncompahgre Peak.

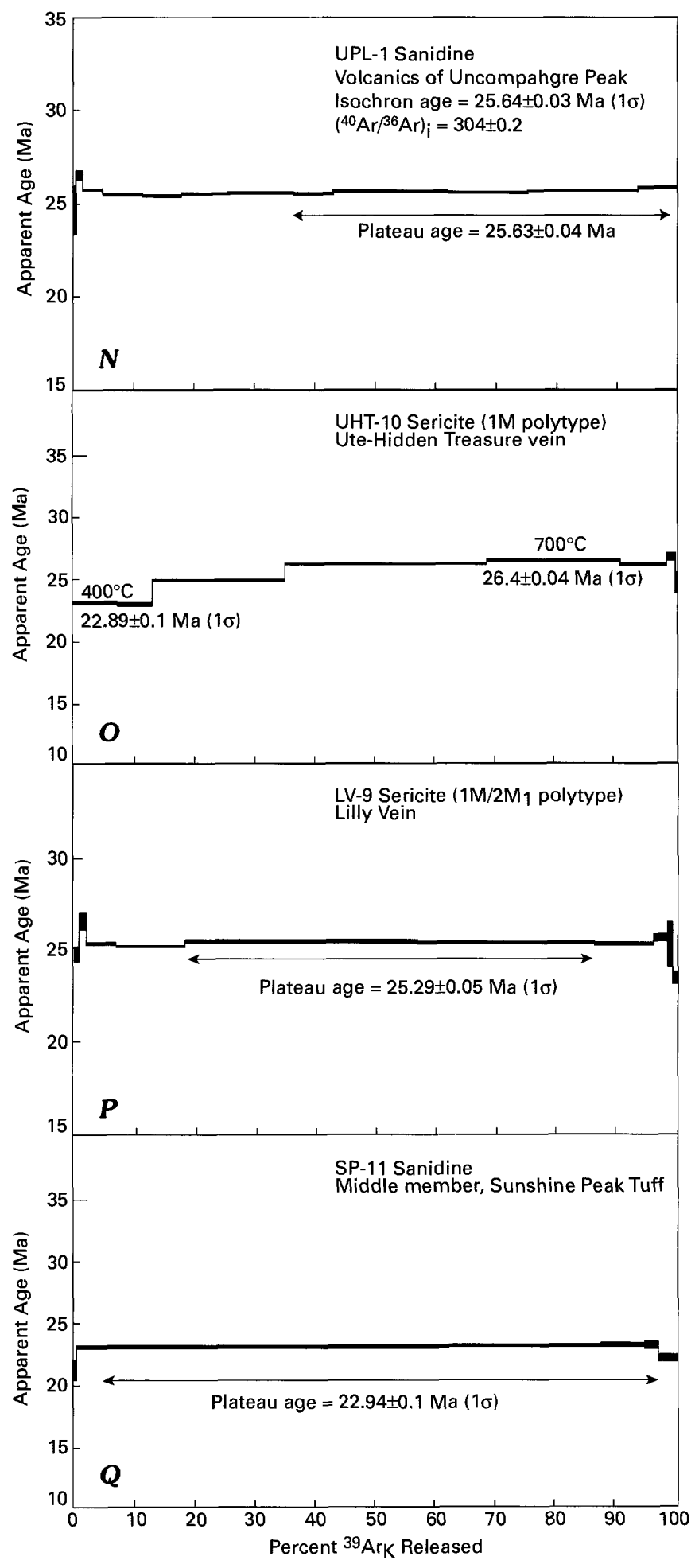

\section{Veins and Porphyry-Style Alteration Related to 26-25 Ma Intrusions}

\section{Geology and Previous Age-Related Studies}

Previous studies of the Middle Fork-Ophir Pass, Capitol City, Iron Beds, and Matterhorn Peak areas (fig. $2 A$ ) document a 


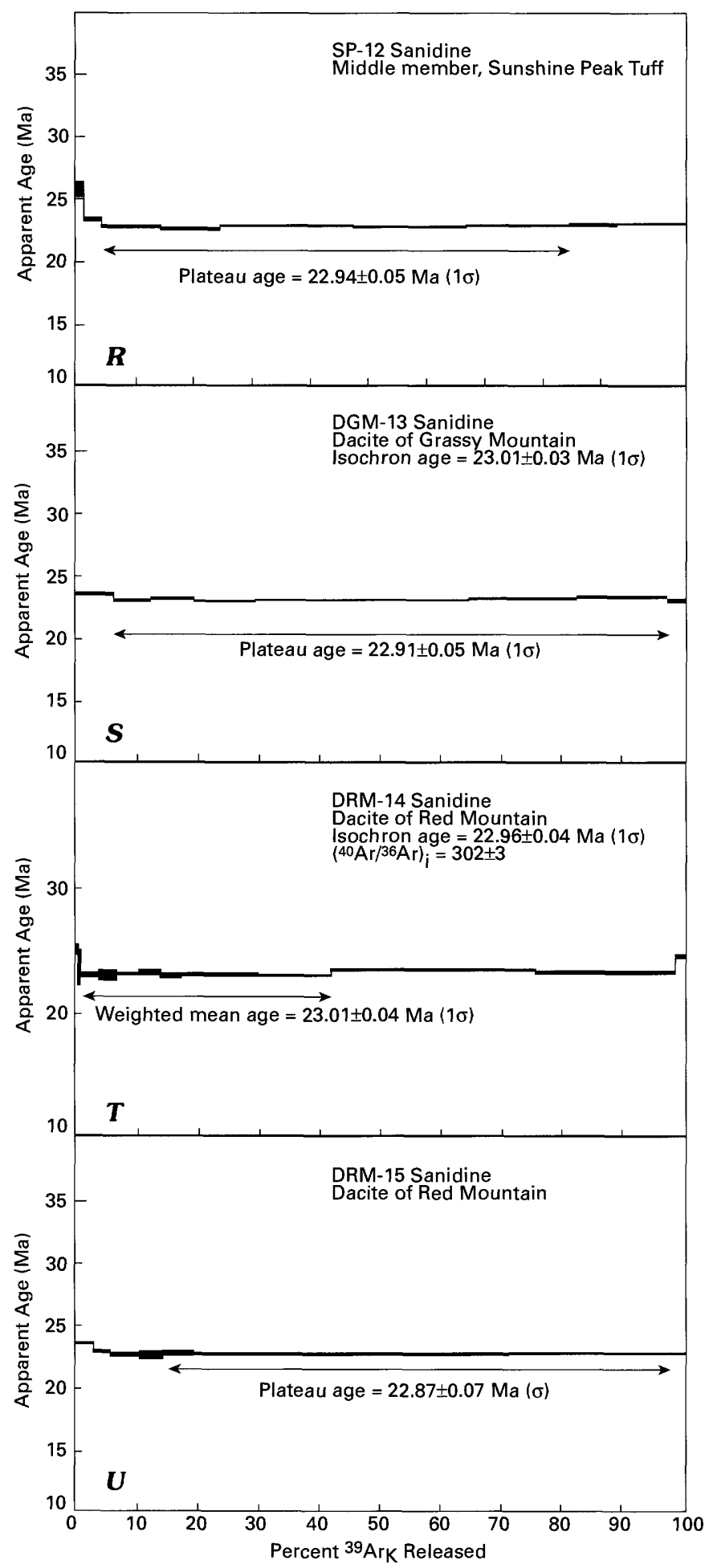

Figure 3-Continued. ${ }^{40} \mathrm{Ar} /{ }^{39} \mathrm{Ar}$ age-spectra for dated samples.

close spatial association between porphyry Mo-Cu mineralization, base-metal sulfide veins, and 26-25 Ma monzonite intrusions (Ringrose and others, 1986; Slack, 1980; Caskey, 1979; Pyle, 1980). A weakly mineralized Mo-Cu porphyry system present in the Middle Fork-Ophir Pass area is temporally and genetically related to a late quartz monzonitic phase $(25 \mathrm{Ma})$ of the Sultan Mountain stock (Ringrose and others, 1986). At the Middle Fork-Ophir Pass locality, quartz-molybdenite stockwork veins associated with intense phyllic alteration are cut by

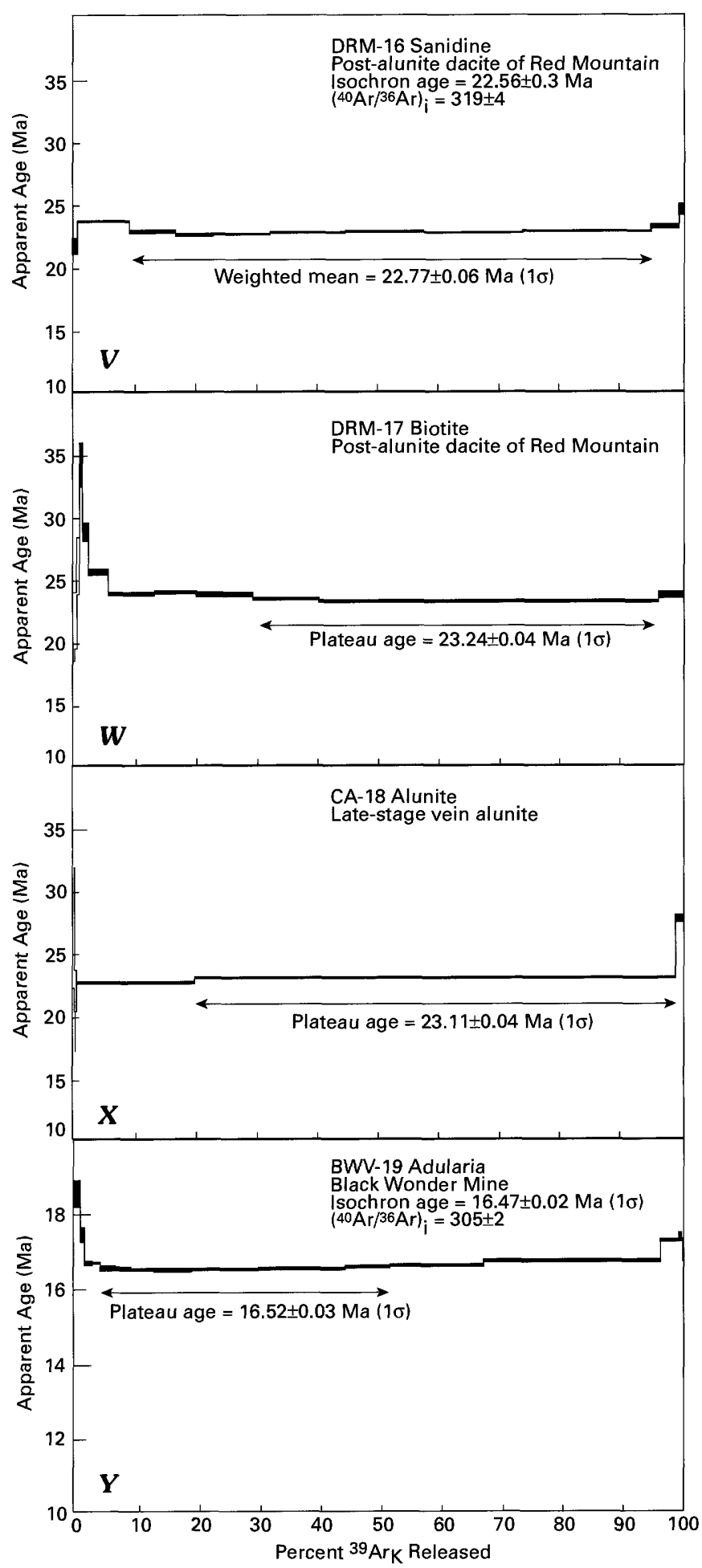

molybdenite-bearing, base-metal veins present mostly on the margins of the porphyry system (R.T. McCusker, written commun. to Amax Exploration, Inc., 1982). Widespread porphyrystyle alteration in the Capitol City area (fig. $2 A$ ) is also spatially associated with several small 26 Ma monzonite to monzogranite porphyry stocks. Veins in this area, which largely correspond to the early quartz-base-metal assemblage of Slack (1980), commonly cut the margins of these intrusions and extend for short distances into surrounding volcanic country rock. 
Table 2. Summary of new geochronologic data for western San Juan mountains and previous K-Ar ages. [ad, adularia; $b$, biotite; sa, sanidine; sc, sericite; al, alunite; $m$, mean age from various minerals]

\begin{tabular}{llll}
\hline Unit & Source & $\begin{array}{c}\text { Mineralization } \\
\text { stage }\end{array}$ & $\begin{array}{c}{ }^{40} \mathrm{Ar} /{ }^{39} \mathrm{Ar} \text { age } \\
\text { Ma } \pm 1 \sigma\end{array}$ \\
\hline Early caldera cycle & Ute Creek caldera & n.a. & \\
Ute Ridge Tuff & Lost Lake caldera & n.a. & $28.63 \pm 0.05 \mathrm{Ma}$ \\
Blue Mesa Tuff & San Juan caldera? & n.a. & $28.40 \pm 0.07 \mathrm{Ma}$ \\
Dillon Mesa Tuff & $\begin{array}{l}\text { San Juan- } \\
\text { Uncompahgre } \\
\text { calderas }\end{array}$ & n.a. & $28.40 \pm 0.04 \mathrm{Ma}$ \\
Sapinero Mesa Tuff & & &
\end{tabular}
Crystal Lake Tuff
Silverton caldera
n.a.
$27.62 \pm 0.07 \mathrm{Ma}$

Regional 26-25 Ma calc-alkaline intrusions and related vein mineralization

Sultan Mountain stock near Silverton

Monzonite intrusion at Capitol City

Volcanics of Uncompahgre Peak

Sericite from Ute-Hidden Treasure vein (Lake City)

n.a.

n.a.

Sericite from Lilly vein near Capitol City

n.a.
26-25 Ma monzonite intrusions

\section{Lake City caldera and related mineralization}

Sunshine Peak Tuff and post-resurgence lavas and intrusions

Lake City caldera and associated magmatism

Coarse-grained vein alunite at Red Mountain

Hydrothermal system at Red Mountain

Sericite from Ute-Hidden Treasure vein (Lake City) n.a. n.a.

n.a.

n.a

Early quartz-basemetal assemblage

Early quartz-basemetal assemblage
$26.60 \pm 0.03 \mathrm{Ma}$

$26.39 \pm 0.1 \mathrm{Ma}$

$25.63 \pm 0.04 \mathrm{Ma}$

$26.40 \pm 0.04 \mathrm{Ma}$

$25.29 \pm 0.05 \mathrm{Ma}$

n.a.

n.a.

$23.11 \pm 0.04 \mathrm{Ma}$

a $23.3 \pm 0.6 \mathrm{Ma}^{7}$ b $30.1 \pm 0.6 \mathrm{Ma}^{1}$

sa $28.1 \pm 0.5 \mathrm{Ma}^{1}$ precious-metal assemblage

$$
22.9 \pm 0.1 \mathrm{Ma} \ddagger
$$

$18.8 \pm 0.4 \mathrm{Ma}$

sa $19.1 \pm 0.3 \mathrm{Ma}^{5}$ sa $19.0 \pm 0.2 \mathrm{Ma}^{5}$ margin of Uncompahgre caldera)

Cuba Gulch rhyolite dike

n.a.

Adularia from Black

Wonder vein n.a.

n.a.

n.a. n.a.

n.a.

$17.1 \pm 0.3 \mathrm{Ma}$

\footnotetext{
${ }^{\dagger}$ Sample contains excess argon and slightly older than 22.93 Ma host rocks.

¥ Apparent age of resetting related to nearby barite-precious-metal vein shoots.

${ }^{\mathrm{n}}$ Not applicable; Age references: ${ }^{1}$ Lipman and others, $1970 ;{ }^{2}$ Jackson, 1980; ${ }^{3}$ Jackson, 1980 (young phase, Sultan Mountain Stock); ${ }^{4}$ Slack, 1980 ;

${ }^{5}$ Lipman and others, 1976; ${ }^{6}$ Hon 1987b; Mehnert and others, 1978; Lipman and others, 1970; Lipman and others, 1976 ; ${ }^{7}$ Mehnert and others, 1979.
} 
The same early quartz-base-metal assemblage is also present in the Ute-Hidden Treasure vein of the Ute-Ulay mine (fig. $2 A$ ), one of the most productive vein systems in the Lake City area (Slack, 1980). Veins of the quartz-base-metal assemblage are mostly present along Henson Creek west of Lake City (Slack, 1980), where most trend northeast, transverse to the ring fault of the Lake City caldera. However, unlike the early quartzbase-metal veins of the Capitol City area, veins of the Ute-Ulay mine are not spatially associated with exposed and altered $26 \mathrm{Ma}$ monzonitic intrusions. Lacking this relationship, earlier studies by Slack $(1976,1980)$ postulated a genetic relationship between the quartz-base-metal veins and the 23 Ma Lake City caldera.

Previous K-Ar determinations from coarse-grained sericite related to porphyry-style phyllic alteration in the Middle ForkOphir Pass area gave ages of $24.9 \pm 0.6 \mathrm{Ma}$ and $25.0 \pm 0.6 \mathrm{Ma}$ (Ringrose and others, 1986); these ages overlap statistically with their quartz monzonite host intrusions that had a weighted mean $\mathrm{K}-\mathrm{Ar}$ date of $25.2 \pm 0.6 \mathrm{Ma}$ (Jackson and others, 1980). Base metal vein mineralization and alteration associated with monzonitic intrusions in the Capitol City, Iron Beds, and Matterhorn Peak areas were not previously dated. However, Lipman and others (1976) described haloes of intensely altered and pyritized rock surrounding the Capitol City intrusions that are truncated abruptly at the topographic wall of the Lake City caldera. Their findings clearly demonstrated that intrusion-related alteration at this locality preceded caldera collapse at $23 \mathrm{Ma}$.

\section{New ${ }^{40} \mathrm{Ar} /{ }^{39} \mathrm{Ar}$ Ages and Interpretations}

Coarse-grained sericite (sample UHT-10) from the early quartz-base-metal assemblage in the Ute-Hidden Treasure vein (fig. $2 A$, loc. 15 ) was previously dated by H.H. Mehnert (in Slack, 1980) using the K-Ar method. However, the validity of this sample's apparent age $(20.1 \pm 0.6 \mathrm{Ma})$ has been questioned due to geologic inconsistencies and relatively large errors associated with the analytical technique (Slack, 1980; Hon and others, 1985). Because establishing accurate age constraints on this significant vein assemblage is important, we redated sericite from sample UHT-10 (Slack, 1980) by the ${ }^{40} \mathrm{Ar} /{ }^{39} \mathrm{Ar}$ method. In addition, we obtained an ${ }^{40} \mathrm{Ar} /{ }^{39} \mathrm{Ar}$ date on sericite from another quartz-base-metal vein (Lilly mine; Irving and Bancroft, 1911) near Capitol City to further constrain vein and intrusive relationships observed there.

${ }^{40} \mathrm{Ar} /{ }^{39} \mathrm{Ar}$ step-heating experiments suggest that $1 \mathrm{M}$ sericite (UHT-10) from the early quartz-base-metal assemblage in the Ute-Hidden Treasure vein originally formed at about 26.4 Ma. The step-up in apparent age with increasing temperature as observed in the age spectrum (fig. $3 O$ ) may indicate an original age of sericite formation as well as an apparent age of resetting. We consider the apparent age from step 5 ( $26.40 \pm 0.04 \mathrm{Ma})$, one of the statistically best steps with highest radiogenic yields, to be the best estimate of the maximum age of the sericite. The apparent resetting at about 22.9 Ma probably records a younger thermal event, which will be discussed in a later section of this report. A sample of green, $1 \mathrm{M} / 2 \mathrm{M}_{1}$ sericite from the Lilly vein (LV-9) about $1 \mathrm{~km}$ north of Capitol City (fig. 2A, loc. 16) rendered an ${ }^{40} \mathrm{Ar} /{ }^{39} \mathrm{Ar}$ plateau age of $25.29 \pm 0.05 \mathrm{Ma}$ (table 1).
An original age of $26.40 \pm 0.04 \mathrm{Ma}$ for the Ute-Hidden Treasure vein sericite (UHT-10) is analytically indistinguishable from that of Capitol City monzonite sample MP-8 $(26.39 \pm 0.1 \mathrm{Ma})$. Sericite from the Lilly vein (LV-9; $25.29 \pm 0.05$ $\mathrm{Ma}$ ) is significantly younger than sericite from the Ute-Hidden Treasure vein, indicating that they formed during two distinct episodes of mineralization. However, these new ages clearly depict the close association between early quartz-base-metal assemblage veins in the Lake City area and 26-25 Ma monzonite intrusions (table 2).

\section{Evolution of the Lake City Caldera}

\section{Geology and Previous Age-Related Studies}

Collapse of the Lake City caldera postdated all other caldera-related eruptions in the western San Juan Mountains by more than 4 million years. The Lake City caldera is thought to be associated with bimodal magmatism related to the onset of extensional tectonism in this general region at about $25 \mathrm{Ma}$ (Lipman and others, 1978). It is surrounded by the older Uncompahgre, San Juan, and Silverton calderas (fig. 1), which formed from 28.4 to 27.5 Ma during an earlier period of volcano-tectonism (Steven and Lipman, 1976).

Initial pyroclastic eruptions from the Lake City caldera were accompanied by large-scale collapse along an arcuate ring fault zone, which also served to control later eruptive vents. The Sunshine Peak Tuff comprises three compositionally distinct ash-flow members (fig. 4) that record eruption from a magma chamber that was zoned downward from high-silica rhyolite to quartz trachyte (Hon and Lipman, 1989; Hon, 1987b). The lower member of the Sunshine Peak Tuff, a high-silica rhyolite (76 percent $\mathrm{SiO}_{2}$ ), marks the onset of pyroclastic activity; it spread widely from the source region and accumulated to a thickness of more than $900 \mathrm{~m}$ within the contemporaneously subsiding caldera (Hon and Lipman, 1989; Hon, 1987b). Subsequent pyroclastic eruptions resulted in recurrent caldera collapse; these eruptions first deposited a 300-m-thick rhyolite unit ( 74 percent $\mathrm{SiO}_{2}$ ), which forms the middle member of the Sunshine Peak Tuff. The middle member has two distinct pumice types: a highsilica rhyolite identical to that in the lower member, and a mafic trachyte ( 65 percent $\mathrm{SiO}_{2}$ ). The upper member is quartz trachyte (67-69 percent $\mathrm{SiO}_{2}$ ) and marked the final pyroclastic eruptions from the zoned magma chamber. No erosional breaks occur within this entire ash-flow sequence, indicating that all three members of the Sunshine Peak Tuff erupted in rapid succession (Hon and Lipman, 1989).

A large quartz syenite pluton was intruded into the intracaldera fill causing resurgence of the Lake City caldera. Intrusion of quartz syenite was accommodated by asymmetric doming and uplift of more than $1 \mathrm{~km}$ along the north-central ring fault. The mineralogic, petrologic, and isotopic characteristics of the resurgent intrusions (Hon and Lipman, 1989; Hon, 1987b) indicate that they were derived from the same alkalic magma chamber that produced the caldera-forming ash-flow eruptions. 


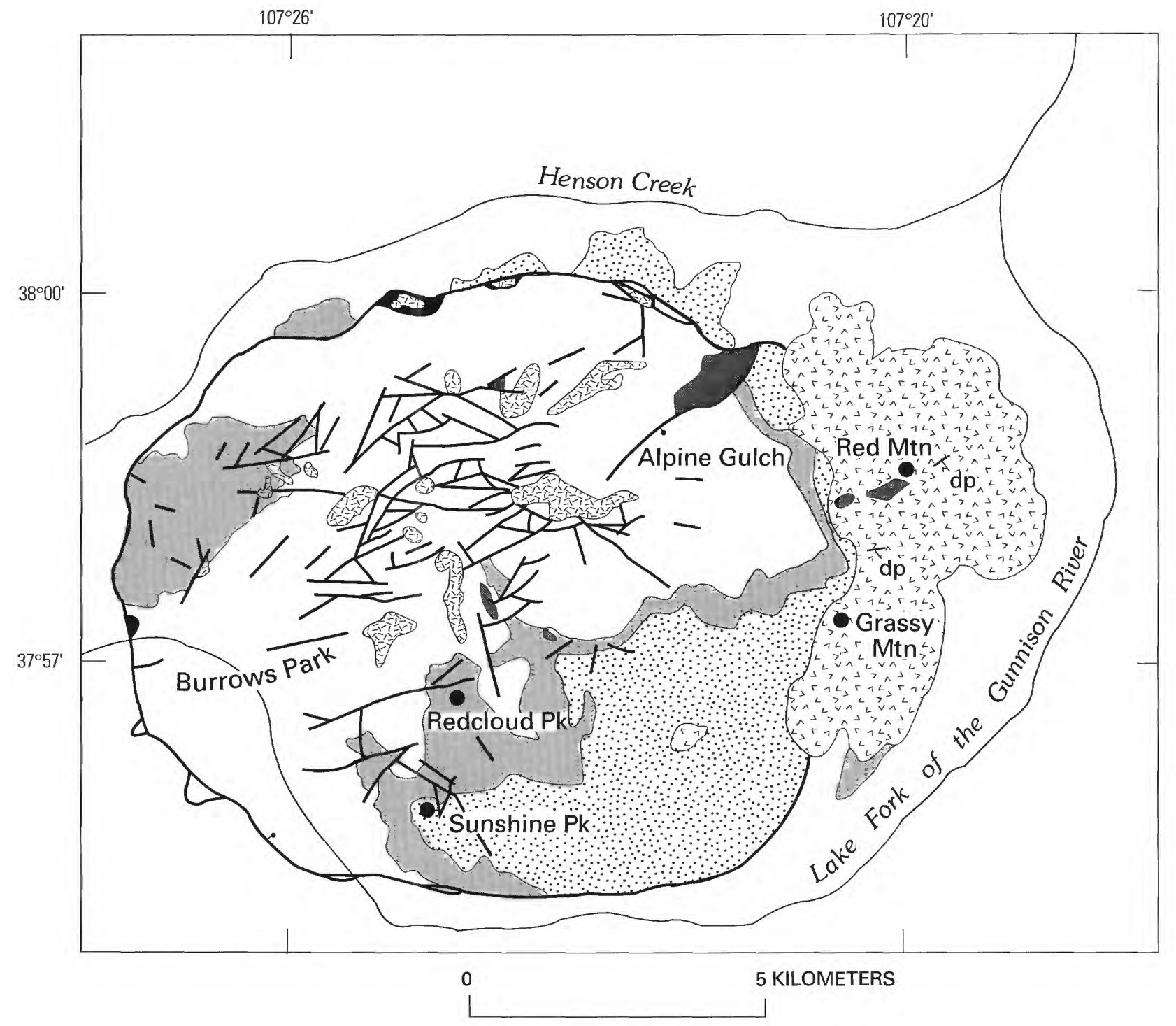

EXPLANATION
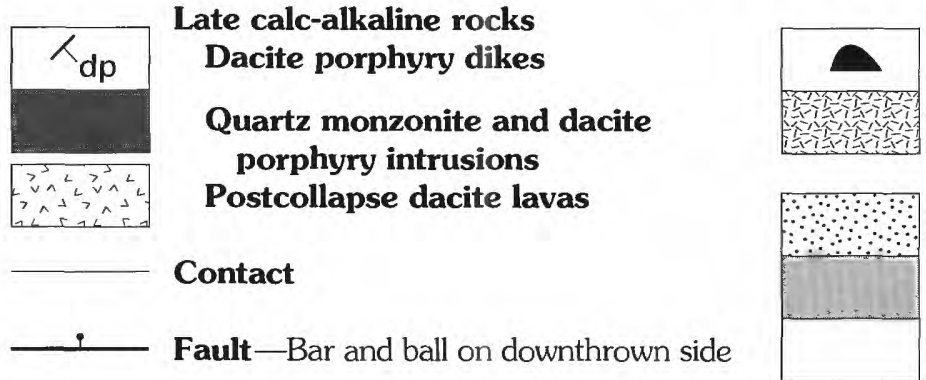

Resurgent intrusions
High-silica rhyolite

Quartz syenite and rhyolite porphyry

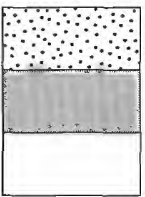

\section{Sunshine Peak Tuff} Upper member

Middle member

Lower member

Figure 4. Generalized geologic map of Lake City caldera (modified from Hon, 1987b).

Continued volcanic activity produced a thick sequence of post-caldera-collapse lavas collectively referred to as the dacite of Grassy Mountain (63-66 percent $\mathrm{SiO}_{2}$ ) (fig. 4). These calc-alkaline lavas and domal masses, which both predate and postdate caldera resurgence, accumulated within the large topographic scallop outside the ring fault on the eastern margin of the caldera.
The last phase of igneous activity within the Lake City caldera was marked by intrusion of the dacite of Red Mountain (63-66 percent $\mathrm{SiO}_{2}$ ) (Bove and Hon, 1992; Bove and others, 1990 ) and the quartz monzonite of Alpine Gulch (67-68 percent $\mathrm{SiO}_{2}$ ) along the east and northeastern sections of the ring fault, respectively (fig. 4). These calc-alkaline intrusions are similar in major-element chemistry, mineralogy, and phenocryst textures, 
and have nearly identical isotopic compositions, suggesting derivation from a common magmatic source. Geophysical data (Grauch, 1987) indicate that a large intrusive body underlies the eastern portion of the caldera, and studies by Hon (1987b) suggest that this body represents the crystallized calc-alkaline magma chamber that fed these intrusions. Geochemical and isotopic data indicate that these intrusions--as well as the dacite lavas of Grassy Mountain-were derived from magma that evolved separately from the main alkaline magma chamber related to caldera eruptions and resurgent intrusion (Hon and Lipman, 1989).

Previous K-Ar determinations were made on 10 mineral separates from rocks-ash-flow tuffs, resurgent intrusions, and preresurgence lavas - representing all stages of development of the Lake City caldera (Lipman and others, 1970; Hon, 1987b; Lipman and others, 1976). The most reliable of these ages range between $22.6 \pm 0.5 \mathrm{Ma}$ and $23.7 \pm 0.4 \mathrm{Ma}$; however, all of these ages within this apparent 1.1 million year time interval are statistically indistinguishable at the 95 percent confidence level. Based on these ages and associated errors, the absolute time span for caldera formation could vary from a maximum of $2 \mathrm{Ma}$ (22.1 to $24.1 \mathrm{Ma}$ ) to a minimum of $0.2 \mathrm{Ma}(23.1$ to $23.3 \mathrm{Ma}$ ) at the $1 \sigma$ confidence level. Further restrictions on the duration of the Lake City caldera cycle have been inferred from paleomagnetic studies (Reynolds and others, 1986), which record emplacement of the ash-flow tuffs and the postcollapse lavas, and initial cooling of the resurgent intrusions during a reversed polarity chron. Based on seafloor records of reversed magnetic periods within the Earth's field from 24 to $22 \mathrm{Ma}$, Reynolds and others (1986) have estimated that the time span from eruption to resurgence of the caldera was probably less than 300,000 years.

\section{New ${ }^{40} \mathrm{Ar} /{ }^{39} \mathrm{Ar}$ Ages and Interpretations}

Seven new ${ }^{40} \mathrm{Ar} /{ }^{39} \mathrm{Ar}$ dates from mineral separates reported here (table 1; fig. 2A) span all stages of development of the Lake City caldera. This study was undertaken to ascertain whether individual phases of caldera activity could be distinguished using the higher analytical precision of the ${ }^{40} \mathrm{Ar} /{ }^{39} \mathrm{Ar}$ step-heating method and to test the time-span estimate of Reynolds and others (1986).

The ages of sanidine samples from silicic (high-silica rhyolite; SP-11) and mafic (trachyte; SP-12) pumice from vitrophyre of the middle member of the Sunshine Peak Tuff (fig. 2A, locs. $17,18)$ precisely constrain the age of emplacement of this unit. The age spectra for both samples are simple (fig. $3 Q, R$ ), and give plateau ages of $22.94 \pm 0.1$ and $22.94 \pm 0.05 \mathrm{Ma}$, respectively. Sanidine from sample DGM-13 from postresurgence dacite of Grassy Mountain lavas (fig. $2 A$, loc. 19) gives a statistically identical plateau age of $22.91 \pm 0.05 \mathrm{Ma}$ (fig. $3 S$ ).

Sanidine from two dikes of the dacite of Red Mountain that crop out southeast (DRM-14) and northeast (DRM-15) of Red Mountain (figs. $2 A$ and 4 , locs. 20,21) were also analyzed. The age spectrum for sample DRM-14 (fig. 3T) displays some excess argon and has a slightly elevated atmospheric intercept $\left[\left({ }^{40} \mathrm{Ar} /\right.\right.$ $\left.{ }^{36} \mathrm{Ar}\right)_{\mathrm{i}}$ ] of $302 \pm 3$ derived from an isochron plot of ${ }^{40} \mathrm{Ar} /{ }^{36} \mathrm{Ar}$ versus ${ }^{39} \mathrm{Ar}{ }^{\beta 6} \mathrm{Ar}$. This sample has an isochron date of $22.96 \pm 0.04$
Ma after eliminating steps 13-14, which exhibit poor analytical reliability. The isochron date is our preferred age and is in close agreement with a statistically valid date of $23.01 \pm 0.04 \mathrm{Ma}$ defined by eight temperature steps from $700^{\circ}$ to $1,050^{\circ} \mathrm{C}$ that contain 41 percent of the released ${ }^{39} \mathrm{Ar}_{\mathrm{K}}$. The age spectrum for sanidine sample DRM-15 (fig. $3 U$ ) is relatively uncomplicated and has a plateau age of $22.87 \pm 0.07 \mathrm{Ma}$ that is represented by four steps containing 86 percent of the released ${ }^{39} \mathrm{Ar}_{\mathrm{K}}$.

Sanidine from a late-stage dike of the dacite of Red Mountain (DRM-16) (fig. 2A, loc. 22, and fig. 4) exhibits a relatively uncomplicated spectrum (fig. $3 \mathrm{~V}$ ) with a plateau age of $22.77 \pm 0.06 \mathrm{Ma}$. The age spectrum from coexisting biotite (sample DRM-17 (fig. $2 A$, loc. 23, and fig. $3 W$ ) ) is complicated, clearly showing the effects of excess argon in the low and high temperature steps. A plateau age of $23.24 \pm 0.04 \mathrm{Ma}$ from the intermediate temperature steps is strikingly discordant with our preferred age from the coexisting sanidine $(22.77 \pm 0.06 \mathrm{Ma})$. Such discordance is common in volcanic biotites, which in some cases have ${ }^{40} \mathrm{Ar} /{ }^{39} \mathrm{Ar}$ ages that are older than those of coexisting sanidine by $0.1-0.2 \mathrm{Ma}$ (Harlan and others, 1998; Kellogg and others, 1994). However, we consider this age unreliable as it is statistically older than all other Lake City ${ }^{40} \mathrm{Ar}{ }^{39} \mathrm{Ar}$ ages that are consistent with geologic data. We consider the $22.77 \mathrm{Ma}$ age of the sanidine to be the best estimate for the age of the late phase of the dacite of Red Mountain intrusions.

Excluding biotite sample DRM-17, all of the previously discussed ages related to Lake City caldera volcanic events are statistically indistinguishable at the 95 percent confidence level and yield a weighted mean age of $22.93 \pm 0.02 \mathrm{Ma}$. The maximum age difference within this set of samples at the $1 \sigma$ level is 330,000 years. Our maximum determined age variance for the lifespan of the caldera is in close agreement with the 300,000-year time span estimated by Reynolds and others (1986), emphasizing the benefit of using these techniques collaboratively.

\section{Hydrothermal Activity and Mineralization Related to the Lake City Caldera}

\section{Geology and Previous Age-Related Studies}

Hydrothermal systems were established both within the core of the Lake City caldera over the cooling resurgent plutons, and along and adjacent to the eastern margin of the caldera contemporaneous with emplacement of late calc-alkaline intrusions. Convective circulation of large volumes of meteoric water around the resurgent plutons and along the western and northern margins of the caldera was related to the formation of veins and associated alteration along extensional faults in the resurgent dome (Hon, 1987a). Veins that formed above the resurgent intrusions appear to have scavenged metals largely from the intracaldera Sunshine Peak Tuff, and have lower base-metal contents than similar veins peripheral to the intrusions (Hon, 1987b). This interpretation is confirmed by lead isotope studies (Sanford, 1992) showing that veins above the intrusions have $\mathrm{Pb}$-isotopic ratios compatible with a lead source from the Sunshine Peak Tuff. Veins on the western 
margin of the caldera, however, have $\mathrm{Pb}$-isotopic ratios indicating that hydrothermal fluids interacted with less radiogenic, precaldera andesites (Lipman and others, 1978), whereas veins on the east side of the caldera have significantly more radiogenic $\mathrm{Pb}$-isotopic ratios (Sanford, 1992), suggesting that vein-related hydrothermal fluids that circulated deeply along the margins of the resurgent pluton interacted with underlying radiogenic Precambrian crystalline rocks.

Massive alunitization (roughly 70 million metric tons of alunite) of postcollapse lavas and intrusions on Red Mountain formed by degassing of sulfur-rich dacitic magmas emplaced along the eastern ring fracture zone (fig. 4) (Bove and others, 1990). Alteration is zoned vertically from alunite downward into phyllic and finally into a deeper potassic assemblage related to emplacement of one or more dacite porphyry intrusions. Subeconomic $\mathrm{Mo}$ and $\mathrm{Cu}$ mineralization also increases with depth and proximity to the deeper potassic alteration assemblage (Bove and Hon, 1992). Replacement alunite, related to the ascent of buoyant magmatic vapor plumes, makes up the largest proportion of alunite at Red Mountain (Bove and others, 1990); however, late-stage, coarse-grained vein alunite is present locally and has been interpreted to have formed by decompression of magmatic steam in open fractures (Bove and others, 1990; Rye and others, 1992). A weakly mineralized quartz monzonite intrusion in nearby Alpine Gulch (fig. 4) is genetically associated with the dacite of Red Mountain intrusions (Hon, 1987b). The Alpine Gulch intrusion has features associated with $\mathrm{Cu}$ and (or) Mo mineralization including fragmental dikes, tourmaline breccias, magnetite veinlets, and quartz veins containing pyrite, hematite, sphalerite, galena, and chalcopyrite (Hon, 1987a). However, alteration haloes are conspicuously absent around this intrusion.

Slack (1980) noted that veins on the east and north sides of the Lake City caldera fill fractures roughly perpendicular to the ring fault that appear to form a radial pattern around the Red Mountain area. This pattern of radial veins that contain the late barite-precious-metal assemblage described by Slack (1980) was postulated to be related to emplacement of the 23 Ma dacite of Red Mountain intrusions (Slack, 1980). Thin veinlets of this late barite-precious-metal assemblage are present in the UteHidden Treasure vein of the Ute-Ulay mine (fig. $2 A$ ) and are shown by Slack (1980, fig. 4) to cut late ore shoots of the quartzbase-metal assemblage. Mixing of meteoric water off the resurgent dome of the caldera, peripheral to the sulfate-rich magmatic plume, may have caused flushing of sulfate from the hydrothermal system into the surrounding radial vein systems (Hon, 1987b).

Previous K-Ar determinations were made on replacement and vein alunite from the Red Mountain complex on the east side of the 23 Ma Lake City caldera by Mehnert and others (1979). Replacement alunite yielded an age of $22.9 \pm 0.8 \mathrm{Ma}$, whereas an age of $23.3 \pm 0.6 \mathrm{Ma}$ was determined on paragenetically later vein alunite. Studies by Hon and others (1985) disproved earlier assertions by Slack (1980), who claimed that the historically productive Golden Fleece vein (Irving and Bancroft, 1911)—geographically situated among barite-preciousmetal veins on the east side of the Lake City caldera (Slack, 1976, 1980)-was contemporaneous with the 23 Ma Red Mountain hydrothermal system. Although originally thought to be part of the barite-precious-metal assemblage (Slack, 1980), late-stage ore minerals from the Golden Fleece vein are mineralogically distinct, containing abundant gold and silver tellurides intergrown locally with minor colloform pitchblende (Hon and others, 1985); pitchblende is unknown elsewhere in the Lake City area (Slack, 1976; Hon and others, 1985). A U$\mathrm{Pb}$ isochron age of $27.5 \pm 0.3 \mathrm{Ma}$ and well-documented geologic relations (Hon and others, 1985) clearly indicate that formation of the Golden Fleece vein preceded collapse of the Lake City caldera.

\section{New ${ }^{40} \mathrm{Ar}{ }^{39} \mathrm{Ar}$ Ages and Interpretations}

Coarse-grained vein alunite from Red Mountain (sample CA-18) (fig. 2A, loc. 24, and fig. 4) exhibits a relatively simple spectrum (fig. $3 X$ ). Two steps yield a plateau age of $23.11 \pm 0.04$ $\mathrm{Ma}$, but this age is statistically older than ${ }^{40} \mathrm{Ar} /{ }^{39} \mathrm{Ar}$ dates for unaltered host rocks. The reason for this discrepancy is unknown, but may be due to the unrecognized presence of uniformly distributed excess ${ }^{40} \mathrm{Ar}$. Because the alunite plateau age is greater than that of the host rocks, we consider this age unreliable. Overall, we consider the weighted mean ${ }^{40} \mathrm{Ar} /{ }^{39} \mathrm{Ar}$ age from all Lake City caldera samples (22.93 Ma) as the preferred age of contemporaneous alunite formation. Similar incongruously old ${ }^{40} \mathrm{Ar} /{ }^{39} \mathrm{Ar}$ dates have also been recorded for replacement alunite from the $23 \mathrm{Ma}$ Summitville deposit in the eastern San Juan Mountains (S. Harlan, oral commun., 1995). As at Red Mountain, these dates postdate the $23.0 \mathrm{Ma}$ dacite porphyry host rock by 100,000 to several hundred thousand years. Alunite from the Summitville mine shows evidence of excess argon in the age spectra, which, combined with the old apparent ages from both areas, may indicate an inherent problem in the isotopic dating of some alunites.

${ }^{40} \mathrm{Ar}{ }^{\beta 9} \mathrm{Ar}$ studies of $1 \mathrm{M}$ sericite (UHT-10) from the UteHidden Treasure vein, located just outside the northern ring fault of the Lake City caldera (fig. $2 A$ ), may indicate both an original age of sericite formation and an apparent age of resetting (fig. $3 O$ ). As discussed previously (see section on 26-25 Ma veins), an apparent age of $26.40 \pm 0.04 \mathrm{Ma}$ is our best estimate of the maximum age of the sericite. However, this sample appears to have experienced partial ${ }^{40} \mathrm{Ar}$ loss at about $22.9 \mathrm{Ma}$ (steps 1 and 2 ) and may record the effects of a younger thermal event. This event may be related to hydrothermal fluids associated with the formation of late-stage, barite-precious-metal veins $<40 \mathrm{~m}$ away. Scanning electron microscope studies of this sample reveal two discrete populations of sericite. We interpret the shape of the spectrum to reflect the combined effects of argon released from both mica populations. The earlier formed, coarser sericite degassed primarily at higher temperatures, whereas the younger and and finer mica fraction degassed at lower temperatures.

Although fission track data for zircon from the Capitol City area (Johnston and Naeser, 1976) probably record a younger thermal event related to the 22.9 Ma Lake City caldera cycle, thermal effects of this event were apparently insufficient to completely reset the ${ }^{40} \mathrm{Ar} /{ }^{39} \mathrm{Ar}$ system of sericite in the nearby Lilly vein (sample LV-9; table 1; fig. $2 A$ ). Thus by analogy, thermal effects from the Lake City caldera likely were also insufficient 
and therefore did not reset the ${ }^{40} \mathrm{Ar} /{ }^{39} \mathrm{Ar}$ systematics of sericite within the Ute-Hidden Treasure vein. In addition, the absence of Lake City caldera-age intrusions north of the ring fracture precludes resetting due to local intrusive activity. Thus by inference we suggest that the late barite-precious-metal assemblage in the Ute-Hidden Treasure vein system formed at 22.9 Ma, and that this age most probably relates the radial barite-preciousmetal veins on the east side of the caldera to intrusive and hydrothermal activity at Red Mountain, as proposed earlier by Slack (1980).

\section{9-17 Ma Rhyolite Intrusions North and South of the Lake City Caldera and Associated Mineralization}

A series of silicic alkalic rhyolite intrusions and one extrusive dome was emplaced along the northern margin of the Uncompahgre caldera about $18.8 \mathrm{Ma}$ (fig. $2 A$ ). These rhyolites are highly enriched in $\mathrm{U}, \mathrm{Li}, \mathrm{Th}, \mathrm{Be}, \mathrm{Mo}$, and $\mathrm{F}$ and are similar petrogenetically to the F-rich, topaz rhyolites described by Burt and Sheridan (1980). The rhyolite bodies are characterized by erratic concentrations of uranium along their fractured margins (Slack, 1976; Steven and others, 1977) and contain late fluorite and topaz as vapor-phase vug-fillings. The volatiles $\mathrm{H}_{2} \mathrm{O}$ and HF were probably depleted during the cooling and crystallization of these magmas and lost as volcanic emanations from fumaroles (Zielinski and others, 1977); outside of local fumarolic alteration and devitrification, these intrusions and the surrounding host rocks are mostly unaltered.

Dikes of high-silica rhyolite associated with mineralized pebble dikes, uranium-mineralized fractures, fluorite, and anomalous molybdenum and tungsten are also present about $2-3 \mathrm{~km}$ south of the Lake City caldera, just southwest of the Sherman townsite (fig. $2 A$ ). In contrast to the $18.8 \mathrm{Ma}$ high-silica rhyolites to the north, these dikes are strongly hydrothermally altered, as is the surrounding granite, and are cut by thin veinlets of microaplitic quartz, pyrite, and sericite. As these rocks have many of the characteristic signatures of Climax-type Mo-porphyry deposits (White and others, 1981), they were the focus of considerable exploration activity in the late 1970's through early 1980's.

South of the Lake City caldera and north of the former townsite of Sherman, a major mineralized structure is hosted almost entirely within a 30-m-thick diabase dike that cuts Precambrian granite (Sanford and others, 1991). The mineralized vein structure, known as the Black Wonder vein (fig. $2 A$ ), is along a highly sheared zone that contains breccia fragments of the diabase dike and the granite. Cockscomb quartz is the dominant vein material and is accompanied by later fluorite and calcite, plus minor adularia, pyrite, chalcopyrite, galena, and barite. Chalcopyrite and pyrite are also disseminated throughout the brecciated wall rock.

Earlier K-Ar determinations from an alkali rhyolite intrusion on the northern margin of the Uncompahgre caldera yielded an age of $19.1 \pm 0.2 \mathrm{Ma}$ (Lipman and others, 1976). This age is confirmed by six nearly identical K-Ar ages (H.H. Mehnert and K. Hon, unpub. data, 1985) from as many of these rhyolites that have a weighted mean age of $18.8 \pm 0.4 \mathrm{Ma}$ (table 5). Previously unpublished $\mathrm{K}-\mathrm{Ar}$ determinations on sanidine from one of the high-silica rhyolite dikes in the Cuba Gulch area yielded a statistically younger age of $17.11 \pm 0.3 \mathrm{Ma}$ (table 5).

The age spectrum (fig. 3Y) for adularia separated from the Black Wonder vein (sample BWV-19) is slightly $U$-shaped, suggesting the presence of excess ${ }^{40} \mathrm{Ar}$. This sample yielded a plateau age of $16.52 \pm 0.03$ Ma over steps $6-14$ with 50 percent of the released ${ }^{39} \mathrm{Ar}_{\mathrm{K}}$. $\mathrm{An}{ }^{40} \mathrm{Ar}{ }^{36} \mathrm{Ar}$ vs. ${ }^{39} \mathrm{Ar} /{ }^{36} \mathrm{Ar}$ isochron plot using all the steps gives an age of $16.47 \pm 0.02 \mathrm{Ma}$ (table 1) with a slightly elevated atmospheric intercept $\left[\left({ }^{40} \mathrm{Ar} /{ }^{36} \mathrm{Ar}\right)_{\mathrm{i}}\right]$ of $305 \pm 2$, which is only slightly higher than the atmospheric value of 295.5. We consider the isochron date $(16.47 \pm 0.02 \mathrm{Ma})$ the preferred age for this sample due to the presence of minor excess ${ }^{40} \mathrm{Ar}$.

The 16.5 Ma date for the Black Wonder vein is the first age to document post-23 Ma vein mineralization in the Lake City area. The similarity in age between the Black Wonder vein and the mineralized rhyolite in Cuba Gulch (17.1 Ma) suggests the likelihood of a genetic association between mineralized veins and intrusion of high-silica rhyolite in this area. The rhyolites to the north of the caldera may be high-level and volatile-poor precursors to the deeper unexposed rhyolite intrusions beneath the Cuba Gulch area.

\section{Discussion and Summary}

Our new ${ }^{40} \mathrm{Ar} /{ }^{39} \mathrm{Ar}$ isotopic dates allow establishment of a significantly more refined chronology of caldera formation and mineralization in the western San Juan Mountains. From these data we document the geochronology of the following events: (1) formation of the Ute Creek (Ute Ridge Tuff), Lost Lake (Blue Mesa Tuff), San Juan-Uncompahgre (Dillon Mesa and Sapinero Mesa Tuffs), and Silverton calderas between 28.6 and $27.6 \mathrm{Ma}$; (2) emplacement of 26.5-25 Ma intermediate-composition intrusions and related subeconomic Mo-Cu porphyry and associated vein mineralization; (3) eruption and resurgent doming of the 22.9 Ma Lake City caldera and temporally associated mineralization in the Lake City area; and (4) emplacement of 18-17 Ma high-silica rhyolite intrusions on the margins of the Lake City caldera and related 16.5 Ma vein mineralization.

Previous K-Ar dates for the Ute Ridge Tuff (30.1 and 28.1 $\mathrm{Ma})$ and Fish Canyon Tuff (27.8 Ma) loosely documented the ages of pre-Lake City-age calderas of the western San Juan Mountains (Lipman and others, 1976). New ${ }^{40} \mathrm{Ar} /{ }^{39} \mathrm{Ar}$ dates, however, precisely constrain the time interval ( 0.8 to 1.1 million years at the $1 \sigma$ level) between emplacement of the Ute Ridge (28.63 Ma) and Crystal Lake Tuffs (27.62 Ma) and show the brief intervening eruptive chronology of the Blue Mesa (28.40 Ma), Dillon Mesa (28.40 Ma), and Sapinero Mesa (28.19 Ma) Tuffs. Integrating our new dates with previously established geologic relationships, we can now determine the time interval for joint resurgence of the San Juan-Uncompahgre calderas. Studies by Luedke and Burbank (1968) showed that resurgent doming began shortly after collapse of the Sapinero Mesa Tuff, before early accumulation of caldera-filling lavas. However, evidence of late stages of resurgence has been recognized in key 
exposures of the Crystal Lake Tuff (Lipman and others, 1973; P.W. Lipman, written commun., 1998), indicating that resurgent doming took place from about 28.2 to $27.6 \mathrm{Ma}$. Our new ${ }^{40} \mathrm{Ar} /$ ${ }^{39} \mathrm{Ar}$ ages are of similar quality to those of Lipman and others (1997) and Lanphere (1988), now enabling correlation of regional ash-flow stratigraphy across the entire San Juan volcanic field.

A regional magmatic event beginning about $26.5 \mathrm{Ma}$ resulted in intrusion of monzonite and quartz monzonite from Wilson Mountain northeast to Capitol City (fig. 2A). This event was probably related to intrusion of a high-level batholith into its own volcanic cover. Ages of sericite from quartz-base-metal veins near Capitol City (25.3 Ma) and Lake City (26.4 Ma) confirm relationships observed in the Middle Fork-Ophir Pass area indicating that these veins formed coevally with various phases of the monzonite intrusions. These new ages indicate a minimum hiatus of about 1 million years between mineralization related to the 26-25 Ma intrusions and pyroclastic eruptions from the 27.6 Ma Silverton caldera.

The Lake City caldera is the youngest of more than 15 collapse calderas that have been recognized within the San Juan volcanic field (Steven and Lipman, 1976; Lipman and others, 1997). Six new ${ }^{40} \mathrm{Ar} /{ }^{39} \mathrm{Ar}$ dates are indistinguishable at the 95 percent confidence level and have a minimum and maximum apparent age variance of 80,000 to 330,000 years at the $1 \sigma$ confidence level. A weighted mean of these determinations yields an age of $22.93 \pm 0.02 \mathrm{Ma}$. A maximum time restriction of 330,000 years for the evolution of the Lake City caldera is consistent with paleomagnetic studies of Reynolds and others (1986); however, our minimum age variance of 80,000 years is more similar to durations known from some other well-dated Pleistocene calderas (Gansecki and others, 1998; Gazis and others, 1995; Hildreth and others, 1984).

Intrusion of the calc-alkaline dacite of Red Mountain late in the Lake City caldera cycle is clearly linked to massive alunitization and related subeconomic Mo-Cu porphyry mineralization at depth. Radial veins of the late barite-precious-metal assemblage (Slack, 1980) located 2-3 km north and east of Red Mountain (fig. 4) are also probably genetically related to the dacite of Red Mountain intrusions. We interpret the sericite from the Ute-Hidden Treasure vein, which originally crystallized at $26.40 \pm 0.04 \mathrm{Ma}$, to have been partially reset at $22.9 \pm 0.1 \mathrm{Ma}$, perhaps by hydrothermal fluids related to nearby veins of the latestage barite-precious-metal assemblage. Based on these data, we concur with the conclusion of Slack (1980) that the late barite-precious-metal veins distributed radially around the east side of the Lake City caldera were associated with $23 \mathrm{Ma}$ hydrothermal activity at Red Mountain. Recharge of meteoric water from the top of the resurgent dome of the caldera may have resulted in the flushing of sulfate and metals from the Red Mountain hydrothermal system into the surrounding moat zone where these veins formed.

Intrusion of compositionally and petrographically similar dacite porphyry took place regionally throughout the San Juan volcanic field at about $23 \mathrm{Ma}$. Calc-alkaline dacite porphyry intrusions at Red Mountain Pass north of Silverton, Summitville (Gray and Coolbaugh, 1994), and those at Red Mountain near Lake City-aside from being related to significant mineralization - were all rich in sulfur and genetically associated with large, acid-sulfate alteration systems (Gilzean, 1984; Lipman and others, 1976; Gray and Coolbaugh, 1994; Bove and others, 1990). Mass-balance studies of hydrothermally altered rocks at Red Mountain (Lake City) document that nearly 14 million metric tons of sulfur was derived from the underlying dacitic magmas (Bove, 1988). Although only speculative, one possible mechanism for sulfur enrichment in these $23 \mathrm{Ma}$ dacitic magmas could have been upward migration of a fluid phase derived from an underplating basaltic magma similar to processes related to the 1991 high- $\mathrm{SO}_{2}$ eruptions at Mount Pinatubo (Pallister and others, 1992). As extrapolated to the $23 \mathrm{Ma}$ setting in the San Juan volcanic field, regional extension and crustal thinning may have promoted the ascent of basaltic magma to higher crustal levels, which then gave rise to the sulfur-rich dacitic magmas.

Economically important post-23 Ma vein mineralization in the western San Juan Mountains appears to be closely associated with intrusion of high-silica alkali rhyolite (Lipman and others, 1973). The distinctive early Miocene (23-16 Ma) quartz-bearing rhyolites in the San Juan Mountains are part of a bimodal igneous suite associated with extensional tectonism that began about $25 \mathrm{Ma}$. These rhyolite intrusions, such as the dikes in Cuba Gulch, south of Lake City (fig. $2 A$ ), and those around Red Mountain Pass north of Silverton (fig. $2 A$ ), are petrologically very similar to Climax-type high-silica rhyolites (White and others, 1981; Lipman and others, 1976) that are associated with large molybdenum porphyry systems in the Western United States.

\section{Acknowledgments}

The authors would like to express their gratitude to Stephen Harlan, who went far beyond his editorial responsibilities in the various stages of this manuscript. Early informal reviews and discussions with Peter Lipman also greatly improved the manuscript. Editorial reviews by Thomas Steven and Philip Bethke are also appreciated.

\section{References Cited}

Bove, D.J., 1988, Evolution of the Red Mountain alunite deposit, Lake City caldera, San Juan Mountains, Colorado: Boulder, Colo., University of Colorado M.A. thesis, $179 \mathrm{p}$.

Bove, D. J., and Hon, Ken, 1992, Geology and alteration map and drill-core logs of the Red Mountain area, near Lake City, Hinsdale County, Colorado: U.S. Geological Survey Miscellaneous Investigations Map I2286.

Bove, D.J., Rye, R.O., and Hon, Ken, 1990, Evolution of the Red Mountain alunite deposit: U.S. Geological Survey Open-File Report 90-0235, 30 p.

Burbank, W.S., and Luedke, R.G., 1969, Geology and ore deposits of the Eureka and adjoining districts San Juan Mountains, Colorado: U.S. Geological Survey Professional Paper 535, 73 p.

Burt, D.M., and Sheridan, M.F., 1980, A model for the formation of uranium/lithophile element deposits in fluorine-enriched volcanic rocks: American Association of Petroleum Geologists, Southwest sectional meeting, Technical Abstracts with Programs, p. 18.

Caskey, D.J., 1979, Geology and hydrothermal alteration of the Iron Beds area, Hinsdale County, Colorado: Austin, Tex., University of Texas M.A. thesis, $110 \mathrm{p}$. 
Cross, C.W., and Larsen, E.S., Jr., 1935, A brief review of the geology of the San Juan region of southwestern Colorado: U.S. Geological Survey Bulletin 843, $138 \mathrm{p}$.

Dalrymple, G.B., and Lanphere, M.A., 1969, Potassium-argon datingPrinciples, techniques, and applications to geochronology: San Francisco, W.H. Freeman, $258 \mathrm{p}$.

1981, Irradiation of samples for (40)Ar/(39)Ar dating using the Geological Survey TRIGA reactor: U.S. Geological Survey Professional Paper 1176, $55 \mathrm{p}$.

Doell, R.R., Dalrymple, G.B., Smith, R. L., and Bailey, R.A., 1968, Paleomagnetism, potassium-argon ages, and geology of rhyolites and associated rocks of the Valles caldera, New Mexico: Geological Society of America Memoir 116, p. 211-248.

Fleck, R.J., Sutter, J.F., and Elliott, D.H., 1977, Interpretation of discordant ${ }^{40} \mathrm{Ar} /{ }^{39} \mathrm{Ar}$ age-spectra of Mesozoic tholeiites from Antarctica: Geochimica et Cosmochimica Act, v. 41, p 15-32.

Gansecki, C.A., Mahood, G.A., and McWilliams, M., 1998, New ages for the climactic eruptions at Yellowstone-Single-crystal ${ }^{40} \mathrm{Ar} /{ }^{39} \mathrm{Ar}$ dating identifies contamination: Geology, v. 26, p. 343-346.

Gazis, C.A., Lanphere, M.A., Taylor, H.P., Jr., and Gurbanov, A., 1995, ${ }^{40} \mathrm{Ar} /$ ${ }^{39} \mathrm{Ar}$ and ${ }^{18} \mathrm{O} /{ }^{16} \mathrm{O}$ studies of the Chegem ash-flow caldera and Eldjurta Granite-Cooling of two late Pliocene igneous bodies in the Greater Caucasus Mountains, Russia: Earth and Planetary Science Letters 134, p. 377-391.

Gilzean, M.N., 1984, Nature of a deep hydrothermal system, Red Mountain district, Colorado: Berkeley, Calif., University of California M.S. thesis, $104 \mathrm{p}$.

Grauch, V. J. S., 1987, Interpretive aeromagnetic map using the horizontal gradient-Lake City caldera area, San Juan Mountains, Colorado: U.S. Geological Survey Geophysical Investigations Map GP-974.

Gray, J.E., and Coolbaugh, M.F., 1994, Geology and geochemistry of Summitville, Colorado-An epithermal acid-sulfate deposit in a volcanic dome: Economic Geology, v. 89, p. 1906-1923.

Harlan, S.S., Duebendorfer, E.M., and Deibert, J.E., 1998, New ${ }^{40} \mathrm{Ar} /{ }^{39} \mathrm{Ar}$ isotopic dates from Miocene volcanic rocks in the Lake Mead area, southern Las Vegas Range, Nevada: Canadian Journal of Earth Sciences, v. 35, p. 495-503.

Hildreth, W., Grunder, A.L., and Drake, R.E., 1984, The Loma Seca Tuff and the Calabozos caldera-A major ash-flow and caldera complex in the southern Andes of central Chile: Geological Society of America Bulletin, v. 95, p. 45-54.

Hon, Ken, 1986, Emplacement and cooling zonation of the intracaldera Sunshine Peak Tuff, Lake City caldera, Colorado, USA: International Volcanological Congress Abstracts, New Zealand, February 1986, p. 48.

1987a, Geologic, alteration, and vein maps of the Redcloud Peak (Lake City caldera) and Handies Peak Wilderness Study Areas, Hinsdale County, Colorado: U.S. Geological Survey Miscellaneous Field Studies Map MF-1949.

1987b, Geologic and petrologic evolution of the Lake City caldera, San Juan Mountains, Colorado: Boulder, Colo., University of Colorado $\mathrm{Ph}$. D. thesis, $244 \mathrm{p}$.

Hon, Ken, and Lipman, P.W., 1989, Western San Juan caldera complex, in Lipman, P.W., ed., Oligocene-Miocene San Juan volcanic field, Colorado: New Mexico Bureau of Mines and Mineral Resources Memoir 46, p. 350-380.
Hon, Ken, and Mehnert, H.H., 1983, Compilation of revised ages of volcanic units in the San Juan Mountains, Colorado; Recalculated K-Ar age determinations using IUGS constants: U.S. Geological Survey Open-File Report 83-668, 19 p.

Hon, K., Ludwig, K.R., Simmons, K.R., Slack, J.F., and Grauch, R.I., 1985, U$\mathrm{Pb}$ isochron age and $\mathrm{Pb}$-isotope systematics of the Golden Fleece vein-Implications for the relationship of mineralization to the Lake City caldera, western San Juan Mountains, Colorado: Economic Geology, v. 80, p. 410-418.

Irving, J.D., and Bancroft, H., 1911, Geology and ore deposits near Lake City, Colorado: U.S. Geological Survey Bulletin 478, 128 p.

Jackson, S.E., Harmon, R.S., Lux, D., Rice, C.M., and Ringrose, C.M., 1980, Isotopic geochemistry and chronology of porphyry-style mineralization near Ophir, San Juan Mountains, Colorado: Geological Society of America Abstracts with Programs, v. 12, p. 454.

Johnston, D.A., and Naeser, C.W., 1976, Timing and duration of episodes of andesitic volcanism, northwestern San Juan Mountains, Colorado: Geological Society of America Abstracts with Programs, v. 8, p. 593-594.

Kellogg, K.S., Harlan, S.S., Mehnert, H.H., Snee, L.W., Pierce, K.L., Hackett, W.R., and Rodgers, D.W., 1994, Major 10.2 Ma rhyolitic volcanism in the eastern Snake River plain, Idaho; isotopic age and stratigraphic setting of the Arbon Valley Tuff Member of the StarlightFormation: U.S. Geological Survey Bulletin 2091, 18 p.

Kunk, M.C., Sutter, J.F., and Naeser, C.W., 1985, High-precision ${ }^{40} \mathrm{Ar} /{ }^{39} \mathrm{Ar}$ ages of sanidine, biotite, hornblende, and plagioclase from the Fish Canyon Tuff, San Juan volcanic field, south-central Colorado: Geological Society of America Abstracts with Programs, v. 17, p. 636.

Lanphere, M.A., 1988, High resolution ${ }^{40} \mathrm{Ar} /{ }^{39} \mathrm{Ar}$ chronology of Oligocene volcanic rocks, San Juan Mountains, Colorado: Geochimica et Cosmochimica Acta, v. 52, p. 1425-1434.

Lipman, P.W., 1976, Geologic map of the Lake City caldera area, western San Juan Mountains, southwestern Colorado: U.S. Geological Survey Miscellaneous Investigations Map 1-962.

1984, The roots of ash flow calderas in western North America; Windows into the tops of granitic batholiths, in Lipman, P.W., Self, S.S., and Heiken, G., eds., Introduction to calderas special issue: Journal of Geophysical Research, v. 89, p. 8801-8841.

Lipman, P.W., Doe, B.R., Hedge, C.E., and Steven, T.A., 1978, Petrologic evolution of the San Juan volcanic field, southwestern Colorado; $\mathrm{Pb}$ and $\mathrm{Sr}$ isotope evidence: Geological Society of America Bulletin, v. 89, p. 59-82.

Lipman, P.W., Dungan, M.A., Brown, L.L., and Deino, A., 1997, Recurrent eruption and subsidence at the Platoro caldera complex, southeastern San Juan volcanic field, Colorado; New tales from old tuffs: Geological Society of America Bulletin, v. 108, p. 1039-1055.

Lipman, P.W., Fisher, F.S., Mehnert, H.H., Naeser, C.W., Luedke, R.G., and Steven, T.A., 1976, Multiple ages of mid-Tertiary mineralization and alteration in the western San Juan Mountains, Colorado: Economic Geology, v. 71, p. 571-588.

Lipman, P.W., Steven, T.A., Luedke, R.G., and Burbank, W.S., 1973, Revised volcanic history of the San Juan, Uncompahgre, Silverton, and Lake City calderas in the western San Juan Mountains, Colorado: U.S. Geological Survey Journal of Research, v. 1, p. 627-642.

Lipman, P.W., Steven, T.A., and Mehnert, H.H., 1970, Volcanic history of the San Juan Mountains, Colorado, as indicated by potassium-argon dating: Geological Society of America Bulletin, v. 81, p. 2329-2352. 
Luedke, R.G., and Burbank, W.S., 1968, Volcanism and cauldron development in the western San Juan Mountains, Colorado, in Epis, R.C., ed., Cenozoic volcanism in the southern Rocky Mountains: Colorado School of Mines Quarterly, v. 63, p. 175-208.

Mehnert, H.H., Slack, J.F., and Cebula, G.T., 1979, K-Ar age of alunite alteration at Red Mountain, Lake City area, western San Juan Mountains, Colorado: U.S. Geological Survey Open-File Report 79-1642, p.

Pallister, J.S., Hoblitt, R.P., and Reyes, A.G, 1992, A basalt trigger for the 1991 eruptions of Pinatubo volcano: Nature, v. 356, p. 426-428.

Pyle, P.F., 1980, Geology and hydrothermal alteration of the Matterhorn Peak stock, Hinsdale County, Colorado: Austin, Tex., University of Texas M.A. thesis, $89 \mathrm{p}$.

Ransome, F.L, 1901, A report on the economic geology of the Silverton quadrangle, Colorado: U.S. Geological Survey Bulletin 182, 265 p.

Reynolds, R.L., Hudson, M.R., and Hon, K., 1986, Paleomagnetic evidence regarding the timing of collapse and resurgence of the Lake City caldera, San Juan Mountains, Colorado: Journal of Geophysical Research, v. 91, p. 9599-9613.

Ringrose, C.R., Harmon, R.S., Jackson, S.E., and Rice, C.M., 1986, Stable isotope geochemistry of a porphyry-style hydrothermal system, West Silverton District, San Juan Mountains, Colorado, U.S.A.: Applied Geochemistry, v.1, p 357-373.

Rye, R.O., Bethke, P.M., and Wasserman, M.D., 1992, The stable isotope geochemistry of acid sulfate alteration: Economic Geology, v. 87, p. 225-262.

Samson, S.D., and Alexander, C.E., 1987, Calibration of the interlaboratory ${ }^{40} \mathrm{Ar} /{ }^{39} \mathrm{Ar}$ dating standard, MMhb-1: Isotope Geoscience, v. 66, p. 2734.

Sanford, R.F, 1992, Lead isotopic compositions and paleohydrology of caldera-related epithermal veins, Lake City, Colorado [abs.]: Geological Society of America Bulletin, v. 104, p. 1236-1245.

Sanford, R.F, Rehn, P., Kirk, A.R., Slack, J.F., and Bove, D., 1991, Mine maps of silver-lead, zinc epithermal deposits in the Lake City area, Hinsdale County, San Juan Mountains, southwestern Colorado: U.S. Geological Survey Miscellaneous Investigations Map I-2152.

Slack, J.F., 1976, Hypogene zoning and multistage vein mineralization in the Lake City area, western San Juan Mountains, Colorado: Stanford, Calif., Stanford University Ph. D. thesis, 327 p.
1980, Multistage vein ores of the Lake City district, western San Juan Mountains, Colorado: Economic Geology, v. 75, p. 963991.

Snee, L.W., Sutter, J.F., and Kelly, W.C., 1988, Thermochronology of economic mineral deposits; Dating the stages of mineralization at Panasqueria, Portugal, by high-precision ${ }^{40} \mathrm{Ar} /{ }^{39} \mathrm{Ar}$ age-spectrum techniques on muscovite: Economic Geology, v. 83, p. 335354.

Steiger, R.H., and Jäger, E., 1977, Subcommission on geochronology, convention on the use of decay constants in geochronology and cosmochronology: Earth and Planetary Science Letters, v. 19, p. 321-329.

Steven, T.A., and Lipman, P.W., 1976, Calderas of the San Juan volcanic field, southwestern Colorado: U.S. Geological Survey Professional Paper 958, $35 \mathrm{p}$.

Steven, T.A., Lipman, P.W., Fisher, F.S., Bieniewski, C.L., Meeves, H.C., Popenoe, P., and Luedke, R.G., 1977, Mineral resources of study areas contiguous to the Uncompahgre Primitive Area, San Juan Mountains, southwestern Colorado, with a section on interpretation of aeromagnetic data: U.S. Geological Survey Bulletin 1391E, $126 \mathrm{p}$.

Steven, T.A., Luedke, R.G., and Lipman, P.W., 1974, Relation of mineralization to calderas in the San Juan volcanic field, southwestern Colorado: U.S. Geological Survey Journal of Research, v. 2, p. 405-409.

Taylor, J.R., 1982, An introduction to error analysis: Mill Valley, Calif., University Science Books, 270 p.

Tweto, Ogden, Steven, T.A., Hail, W.J., Jr., and Moench, R.H., 1976, Preliminary geologic map of the Montrose $1^{\circ} \times 2^{\circ}$ quadrangle, southwestern Colorado: U.S. Geological Survey map MF-761.

Varnes, D.J., 1963, Geology and ore deposits of the south Silverton mining area, San Juan County, Colorado: U.S. Geological Survey Professional Paper 378-A, $56 \mathrm{p}$.

White, W.W., Bookstrom, A.A., Kamilli, R.J., Ganster, M.J., Smith, R.P., Ranta, D.E., and Steininger, R.C., 1981, Character and origin of Climax-type molybdenum deposits: Economic Geology, 75th Anniversary Volume, p. 270-316.

Zielinski, R.A., Lipman, P.W., and Millard, H.T., 1977, Minor-element abundances in obsidian, perlite, and felsite of calc-alkaline rhyolites: American Mineralogist, v. 62, p. 426-437.

Manuscript approved for publication December 20, 2000

Published in the Central Region, Denver, Colorado

Graphics by the author and Alessandro J. Donatich

Photocomposition by Norma J. Maes and L.M. Carter

Edited by L.M. Carter 


\section{Appendix}

Table 3. Sample descriptions and localities (note localities also shown in fig. $2 A$ and $B$ ).

1. $37^{\circ} 46^{\prime} 19^{\prime \prime} 107^{\circ} 21^{\prime} 46^{\prime \prime}$ (UR-1) Ute Ridge Tuff from outcrops near the Rio Grande Reservoir, southwest of Finger Mesa at elevation of $2,910 \mathrm{~m}$, Finger Mesa quadrangle.

2. $38^{\circ} 21^{\prime} 47^{\prime \prime} 107^{\circ} 22^{\prime} 09^{\prime \prime}$ (BM-2) Blue Mesa Tuff collected from pyroclastic sequence about $1 \mathrm{~km}$ south of U.S. Highway 50, on the road to Arrowhead Lodge at elevation of $2,741 \mathrm{~m}$, Poison Draw quadrangle.

3. $37^{\circ} 58^{\prime} 18^{\prime \prime} 107^{\circ} 43^{\prime} 43^{\prime \prime}$ (BM-3) Blue Mesa Tuff from vitrophyre near Potosi Peak, northeast of Telluride. Unit Tpg3 of Gilpin Peak sequence of Burbank and Luedke (1969). Elevation at 3,868 $\mathrm{m}$, Telluride quadrangle.

4. $38^{\circ} 10^{\prime} 48^{\prime \prime} 107^{\circ} 20^{\prime} 35^{\prime \prime}$ (DM-3) Single pumice of Dillon Mesa Tuff collected from outcrops at the south edge of Alpine Plateau, just south of the southern mapped extent of Hinsdale basalt flows. Elevation at 3,222 m, Alpine Plateau quadrangle.

5. 37 $58^{\prime} 23^{\prime \prime} 107^{\circ} 43^{\prime} 43^{\prime \prime}$ (DM-4) Basal vitrophyre of Dillon Mesa Tuff near Potosi Peak, northeast of Telluride. Unit Tpg5 of Gilpin Peak sequence of Burbank and Luedke (1969). Elevation at $4,006 \mathrm{~m}$, Telluride quadrangle.

6. $38^{\circ} 17^{\prime} 38^{\prime \prime} 107^{\circ} 12^{\prime} 02^{\prime \prime}$ (SM-4) Fiamme from vitrophyre of Sapinero Mesa Tuff in Dutch Gulch, near Gateview. Elevation at $2,522 \mathrm{~m}$, Gateview quadrangle.

7. $38^{\circ} 23^{\prime} 36^{\prime \prime} 107^{\circ} 11^{\prime} 43^{\prime \prime}$ (SM-5) Vitrophyre of the Sapinero Mesa Tuff collected near Ten Mile Spring on Sapinero Mesa, about 10 $\mathrm{km}$ southeast of Sapinero. Elevation at 2,477 m, Carpenter Ridge quadrangle.

8. 3759'18" 107²44'56" (SM-6) Basal vitrophyre of Sapinero near Potosi Peak, northeast of Telluride. Unit Tpg6 of Gilpin Peak sequence of Burbank and Luedke (1969). Elevation at 4,052 m, Ironton quadrangle.

9. $38^{\circ} 04^{\prime} 07^{\prime \prime} 107^{\circ} 25^{\prime} 45^{\prime \prime}$ (CL-6) Vitrophyre of Crystal Lake Tuff in upper Nellie Creek near Uncompahgre Peak, Uncompahgre Peak quadrangle. Elevation at $3,536 \mathrm{~m}$.

10. $37^{\circ} 49^{\prime} 08^{\prime \prime} 107^{\circ} 12^{\prime} 47^{\prime \prime}$ (CL-7) Crystal Lake Tuff near Hermit Lakes, in the South Clear Creek drainage at elevation 3,050 m. Finger Mesa quadrangle.

11. 37 $47^{\circ} 56^{\prime \prime} 107^{\circ} 43^{\prime} 15^{\prime \prime}$ (SM-1) Quartz monzonite phase of Sultan Mountain stock collected at 2,945 m, Silverton quadrangle.

12. 37\%49'05" 107 39'52" (SM-2) Quartz monzonite phase of Sultan Mountain stock collected at 2,990 m, Silverton quadrangle.

13. 38 $38^{\circ} 44^{\prime \prime} 107^{\circ} 27^{\prime} 55^{\prime \prime}$ (MP-8) Fresh monzonite porphyry collected from a small mine dump on the North Fork of Henson Creek, near the former townsite of Capitol City. Although monzonite porphyry is exposed in adit, freshest sample was found on mine dump. Elevation at about $2,882 \mathrm{~m}$, Uncompahgre Peak quadrangle.

14. $38^{\circ} 04^{\prime} 18^{\prime \prime} 107^{\circ} 27^{\prime} 43^{\prime \prime}$ (UPL-1) Fresh dacite porphyry flows in the upper part of the volcanics of Uncompahgre Peak. Collected at 4,333 $\mathrm{m}$ near the top of Uncompahgre Peak in the Uncompahgre Peak quadrangle.

15. $38^{\circ} 02^{\prime} 05^{\prime \prime} 107^{\circ} 22^{\prime} 05^{\prime \prime}$ (UHT-10) Vein sericite from the UteHidden Treasure vein of the Ute-Ulay mine. Sample collected about $30 \mathrm{~m}$ before the end of the main 5th level adit (Sample UHT-555 of Slack, 1980, fig. 8). The sericite is pale green and is present as discontinuous lenses $(<1 \mathrm{~cm}$ thick and up to several centimeters long) in massive fine-grained rhodochrosite within the paragenetically later parts of stage Ic (part of quartzbase-metal assemblage). Sample collected $<40 \mathrm{~m}$ from younger barite-precious-metal vein assemblage (Slack, 1980). Elevation about $2,795 \mathrm{~m}$, Lake City quadrangle.

16. 38 $31^{\circ} 47^{\prime \prime} 107^{\circ} 28^{\prime} 00^{\prime \prime}$ ( LV-9) Sample collected from an outcrop of the Lilly vein on the north side of Yellowstone Gulch about $1 \mathrm{~km}$ north of Capitol City. Sericite is directly in contact with largely barren, massive to crudely banded white quartz that is capped by late crystals of small euhedral quartz. Sericite is relatively coarse and is present along the contact between the outer edge of the vein and altered wall rock. Elevation at 3,156 m, Uncompahgre Peak quadrangle.

17. $37^{\circ} 56^{\prime} 44^{\prime \prime} 107^{\circ} 23^{\prime} 50^{\prime \prime}$ (SP-12) Black vitrophyric pumice from the middle member of the Sunshine Peak Tuff. Head of the Middle Fork of Alpine Gulch, Redcloud Peak quadrangle at 3,975 m.

18. $37^{\circ} 56^{\prime} 46^{\prime \prime} 107^{\circ} 24^{\prime} 45^{\prime \prime}$ (SP-11) Black vitrophyric pumice from middle member of Sunshine Peak Tuff. Collected from ridge dividing Silver Creek and Bent Creek, Redcloud Peak quadrangle.

19. 37 $59^{\prime} 21^{\prime \prime} 107^{\circ} 19^{\prime} 20^{\prime \prime}$ (DGM-13) Black vitrophyric lava of the dacite of Grassy Mountain just south of the top of Round Mountain. Elevation at 3,521 m, Lake San Cristobal quadrangle.

20. $37^{\circ} 58^{\prime} 27^{\prime \prime} 107^{\circ} 20^{\prime} 13^{\prime \prime}$ (DRM-14) Fresh dike of the dacite porphyry of Red Mountain located about $1.5 \mathrm{~km}$ south of Red Mountain at the head of Red Mountain Gulch. Elevation at 3,465 $\mathrm{m}$, Lake San Cristobal quadrangle.

21. 37 $58^{\prime} 55^{\prime \prime} 107^{\circ} 19^{\prime} 21^{\prime \prime}$ (DRM-15) Fresh dike, dacite of Red Mountain about $1 \mathrm{~km}$ northeast of Red Mountain. Lake San Cristobal quadrangle at $3,506 \mathrm{~m}$.

22. and 23. (DRM-16; DRM-17) Porphyro-aphanitic dacite porphyry dike. Latest intrusive phase of the dacite porphyry of Red Mountain; only phase of dacite of Red Mountain that postdates alunite alteration. Sample from $202 \mathrm{~m}$ depth in drill hole LC-1 collared on southwest side of Red Mountain (Bove and Hon, 1992), in Lake San Cristobal quadrangle.

24. (CA-18) Late-stage, coarse-grained vein alunite (Stage 4 alunite; Bove and others, 1990) collected at $29 \mathrm{~m}$ depth from drill hole LC-3 (Bove and Hon, 1992) collared about $1.3 \mathrm{~km}$ southwest of Red Mountain. Lake San Cristobal quadrangle.

25. $37^{\circ} 54^{\prime} 15^{\prime \prime} 107^{\circ} 25^{\prime} 25^{\prime \prime}$ (BWV-19) Adularia from vein material from the Black Wonder mine, hosted almost entirely within a 30$\mathrm{m}$-thick Ordovician-Cambrian diabase dike. The mineralized vein structure is along a highly sheared zone that contains breccia fragments of the diabase dike and granite from the surrounding wallrock. Cockscomb quartz is the dominant vein material, and it is accompanied by later fluorite and calcite, plus minor adularia, pyrite, chalcopyrite, galena, and barite. Mine located at an elevation of 3,109 m, less than $1 \mathrm{~km}$ north of the Sherman townsite in the Redcloud Peak quadrangle.

26. $38^{\circ} 00^{\prime} 30^{\prime \prime} 107^{\circ} 31^{\prime} 55^{\prime \prime}$ (80L-106A) Rhyolite vitrophyre from extrusive dome at Dolly Varden Mountain. Elevation 3,884 m, Handies Peak quadrangle.

27. 37 $39^{\prime} 30^{\prime \prime} 107^{\circ} 31^{\prime} 58^{\prime \prime}$ (1-6-1D) Rhyolite vitrophyre from intrusion near the junction of the North Fork of Henson Creek and Mary Alice Creek. Elevation at 3,024 m, Weterhorn Peak quadrangle.

28. $38^{\circ} 02^{\prime} 28^{\prime \prime} 107^{\circ} 28^{\prime} 00^{\prime \prime}$ (80L-103) Rhyolite vitrophyre collected from the Broken Hill sill just east of Broken Hill at 3,797 m. Uncompahgre Peak quadrangle.

29. $38^{\circ} 03^{\prime} 42^{\prime \prime} 107^{\circ} 24^{\prime} 37^{\prime \prime}(80 \mathrm{~L}-111 \mathrm{~A})$ Intrusion of rhyolite from prominent peak just north of the upper fork of Nellie Creek. Uncompahgre Peak quadrangle at $3,767 \mathrm{~m}$.

30. $38^{\circ} 04^{\prime} 15^{\prime \prime} 107^{\circ} 20^{\prime} 27^{\prime \prime}(80 \mathrm{~L}-110)$ Rhyolite felsite from intrusion in the upper reaches of Larson Creek. Elevation at 3,024 m, Lake City quadrangle.

31. $37^{\circ} 53^{\prime} 05^{\prime \prime} 107^{\circ} 29^{\prime} 30^{\prime \prime}$ (RC-5-2A) Dike of high-silica rhyolite near the intersection of Cuba Gulch and Snare Creek. Elevation at 3,327 $\mathrm{m}$, Redcloud Peak quadrangle. 
Table 4. ${ }^{40} \mathrm{Ar} /{ }^{39} \mathrm{Ar}$ data for mineral separates from rocks and mineralized material from western San Juan Mountains.

\begin{tabular}{|c|c|c|c|c|c|c|c|}
\hline $\begin{array}{l}\text { Temp. } \\
\left({ }^{\circ} \mathrm{C}\right)\end{array}$ & $\begin{array}{l}\text { Radiogenic }{ }^{a+0} \mathrm{Ar} \\
\text { (V) }\end{array}$ & $\begin{array}{l}\text { K-derived } \\
{ }^{39} \mathrm{Ar}(\mathrm{v})\end{array}$ & $\begin{array}{l}{ }^{40} \mathrm{Ar}{ }^{39} \mathrm{Ar} \\
\text { ratio }\end{array}$ & $\begin{array}{l}{ }^{39} \mathrm{Ar} /{ }^{37} \mathrm{Ar} \\
\text { ratio }\end{array}$ & $\begin{array}{l}\text { Radiogenic } \\
\text { yield }(\%)\end{array}$ & $\%{ }^{39} \mathrm{Ar}$ & $\begin{array}{l}\text { Apparent age and error } \\
(\mathrm{Ma} \text { at } 1 \sigma \text { ) }\end{array}$ \\
\hline \multicolumn{6}{|c|}{$\begin{array}{l}\text { Sample: UR-1 Ute Ridge Tuff } \\
\text { Measured }{ }^{40} \mathrm{Ar} /{ }^{36} \mathrm{Ar}=298.9\end{array}$} & \multicolumn{2}{|c|}{$\begin{array}{l}\text { Sanidine; } 59.0 \mathrm{mg} \\
J \text { - value }=.007551 \pm .1(1 \sigma)\end{array}$} \\
\hline 700 & 0.00731 & 0.0107 & 0.684 & 7.84 & 6.8 & 0.1 & $9.3 \pm 3.27$ \\
\hline 800 & 0.34276 & 0.1606 & 2.134 & 10.95 & 42.9 & 1.6 & $28.84 \pm \quad .08$ \\
\hline 900 & 0.77042 & 0.3617 & 2.130 & 8.33 & 89.2 & 3.5 & $28.79 \pm .09$ \\
\hline 1000 & 1.53864 & 0.7283 & 2.113 & 8.56 & 94.4 & 7.0 & $28.55 \pm \quad .09$ \\
\hline 1050 & 1.54720 & 0.7308 & 2.117 & 9.79 & 95.4 & 7.1 & $28.61 \pm .09$ \\
\hline 1100 & 2.04625 & 0.9684 & 2.113 & 11.51 & 96.0 & 9.4 & $28.56 \pm .04$ \\
\hline 1150 & 2.47059 & 1.1640 & 2.123 & 14.16 & 97.0 & 11.3 & $28.68 \pm .06$ \\
\hline 1200 & 2.42818 & 1.1398 & 2.130 & 16.11 & 97.5 & 11.0 & $28.79 \pm .04$ \\
\hline 1250 & 2.71143 & 1.2779 & 2.122 & 21.45 & 97.1 & 12.4 & $28.67 \pm \quad .06$ \\
\hline 1300 & 4.27081 & 1.9979 & 2.138 & 33.36 & 97.5 & 19.3 & $28.89 \pm .04$ \\
\hline 1350 & 3.36476 & 1.5678 & 2.146 & 37.50 & 97.4 & 15.2 & $29.00 \pm .04$ \\
\hline 1450 & 0.47836 & 0.2275 & 2.103 & 13.47 & 90.5 & 2.2 & $28.42 \pm .13$ \\
\hline \multirow{2}{*}{\multicolumn{3}{|c|}{$\begin{array}{l}\text { Total - Gas } \\
\text { Plateau date }\left(1000^{\circ}-1250^{\circ} \mathrm{C}\right)\end{array}$}} & 2.126 & & & & $28.74 \pm .07$ \\
\hline & & & & & & & $28.57 \pm \quad .08$ \\
\hline \multicolumn{6}{|c|}{$\begin{array}{l}\text { Sample: BM-2 Blue Mesa Tuff } \\
\text { Measured }{ }^{40} \mathrm{Ar}{ }^{\beta 6} \mathrm{Ar}=297.0\end{array}$} & \multicolumn{2}{|c|}{$\begin{array}{l}\text { Sanidine; } 60.1 \mathrm{mg} \\
J \text { - value }=.007559 \pm .1 \%(1 \sigma)\end{array}$} \\
\hline 700 & 0.01288 & 0.00337 & 3.816 & 33.11 & 9.5 & 0.1 & $51.30 \pm 6.29$ \\
\hline 800 & 0.18312 & 0.08499 & 2.155 & 59.80 & 38.0 & 1.3 & $29.14 \pm .70$ \\
\hline 900 & 0.53721 & 0.26176 & 2.052 & 59.59 & 90.4 & 3.9 & $27.77 \pm .08$ \\
\hline 1000 & 1.31802 & 0.62876 & 2.096 & 59.27 & 95.6 & 9.5 & $28.36 \pm \quad .05$ \\
\hline 1050 & 0.99207 & 0.47174 & 2.103 & 58.43 & 96.8 & 7.1 & $28.45 \pm .09$ \\
\hline 1100 & 1.09531 & 0.52430 & 2.089 & 60.91 & 97.2 & 7.9 & $28.26 \pm .04$ \\
\hline 1150 & 1.65374 & 0.78793 & 2.099 & 61.85 & 98.0 & 11.9 & $28.40 \pm \quad .09$ \\
\hline 1200 & 1.46323 & 0.69605 & 2.102 & 62.07 & 98.3 & 10.5 & $28.44 \pm .08$ \\
\hline 1250 & 1.66555 & 0.65975 & 2.101 & 63.32 & 98.5 & 22.3 & $28.40 \pm \quad .06$ \\
\hline 1300 & 2.78365 & 1.32758 & 2.097 & 64.33 & 98.4 & 20.0 & $28.37 \pm \quad .07$ \\
\hline 1350 & 1.75271 & 0.83351 & 2.103 & 64.79 & 97.1 & 12.5 & $28.45 \pm .04$ \\
\hline 1450 & 0.34991 & 0.16343 & 2.141 & 63.44 & 96.4 & 2.5 & $28.96 \pm .15$ \\
\hline \multicolumn{3}{|c|}{$\begin{array}{l}\text { Total - Gas } \\
\text { Plateau date }\left(1000^{\circ}-1350^{\circ} \mathrm{C}\right)\end{array}$} & 2.100 & & & & $\begin{array}{l}28.41 \pm .08 \\
28.40 \pm .07\end{array}$ \\
\hline \multicolumn{6}{|c|}{$\begin{array}{l}\text { Sample: } \mathrm{BM}-3 \text { Blue Mesa Tuff } \\
\text { Measured }{ }^{40} \mathrm{Ar} r^{\beta 6} \mathrm{Ar}=298.9\end{array}$} & \multicolumn{2}{|c|}{$\begin{array}{l}\text { Sanidine; } 57.9 \mathrm{mg} \\
J-\text { value }=.007394 \pm .1 \%(1 \sigma)\end{array}$} \\
\hline 900 & 0.08649 & 0.05499 & 1.573 & 25.64 & 46.3 & 0.5 & $20.86 \pm .19$ \\
\hline 1000 & 0.76485 & 0.36371 & 2.103 & 24.59 & 59.2 & 3.3 & $27.83 \pm .15$ \\
\hline 1100 & 1.02447 & 0.48661 & 2.105 & 34.09 & 93.1 & 4.5 & $27.87 \pm .04$ \\
\hline 1200 & 1.24364 & 0.58990 & 2.108 & 41.14 & 94.5 & 5.4 & $27.90 \pm \quad .06$ \\
\hline 1250 & 1.46346 & 0.68821 & 2.126 & 46.91 & 95.4 & 6.3 & $28.14 \pm \quad .07$ \\
\hline 1300 & 1.78006 & 0.83672 & 2.127 & 47.67 & 96.0 & 7.7 & $28.16 \pm .04$ \\
\hline 1350 & 2.04508 & 0.95664 & 2.138 & 46.15 & 96.5 & 8.8 & $28.29 \pm \quad .05$ \\
\hline 1400 & 2.37909 & 1.11449 & 2.135 & 46.34 & 95.8 & 10.2 & $28.25 \pm \quad .08$ \\
\hline 1450 & 3.57580 & 1.67640 & 2.133 & 49.61 & 94.7 & 15.4 & $28.23 \pm .04$ \\
\hline 1500 & 5.64558 & 2.63270 & 2.144 & 54.64 & 93.7 & 24.1 & $28.38 \pm \quad .04$ \\
\hline 1550 & 2.50126 & 1.15848 & 2.159 & 49.58 & 94.3 & 10.6 & $28.57 \pm .04$ \\
\hline 1650 & 0.74579 & 0.35358 & 2.109 & 35.23 & 88.8 & 3.2 & $27.92 \pm \quad .04$ \\
\hline \multirow{2}{*}{\multicolumn{3}{|c|}{$\begin{array}{l}\text { Total - Gas } \\
\text { Plateau date }\left(1350^{\circ}-1500^{\circ} \mathrm{C}\right)\end{array}$}} & 2.131 & & & & $28.20 \pm \quad .06$ \\
\hline & & & & & & & $28.30 \pm .05$ \\
\hline
\end{tabular}


Table 4-Continued. ${ }^{40} \mathrm{Ar} /{ }^{39} \mathrm{Ar}$ data for mineral separates from rocks and mineralized material from western San Juan Mountains.

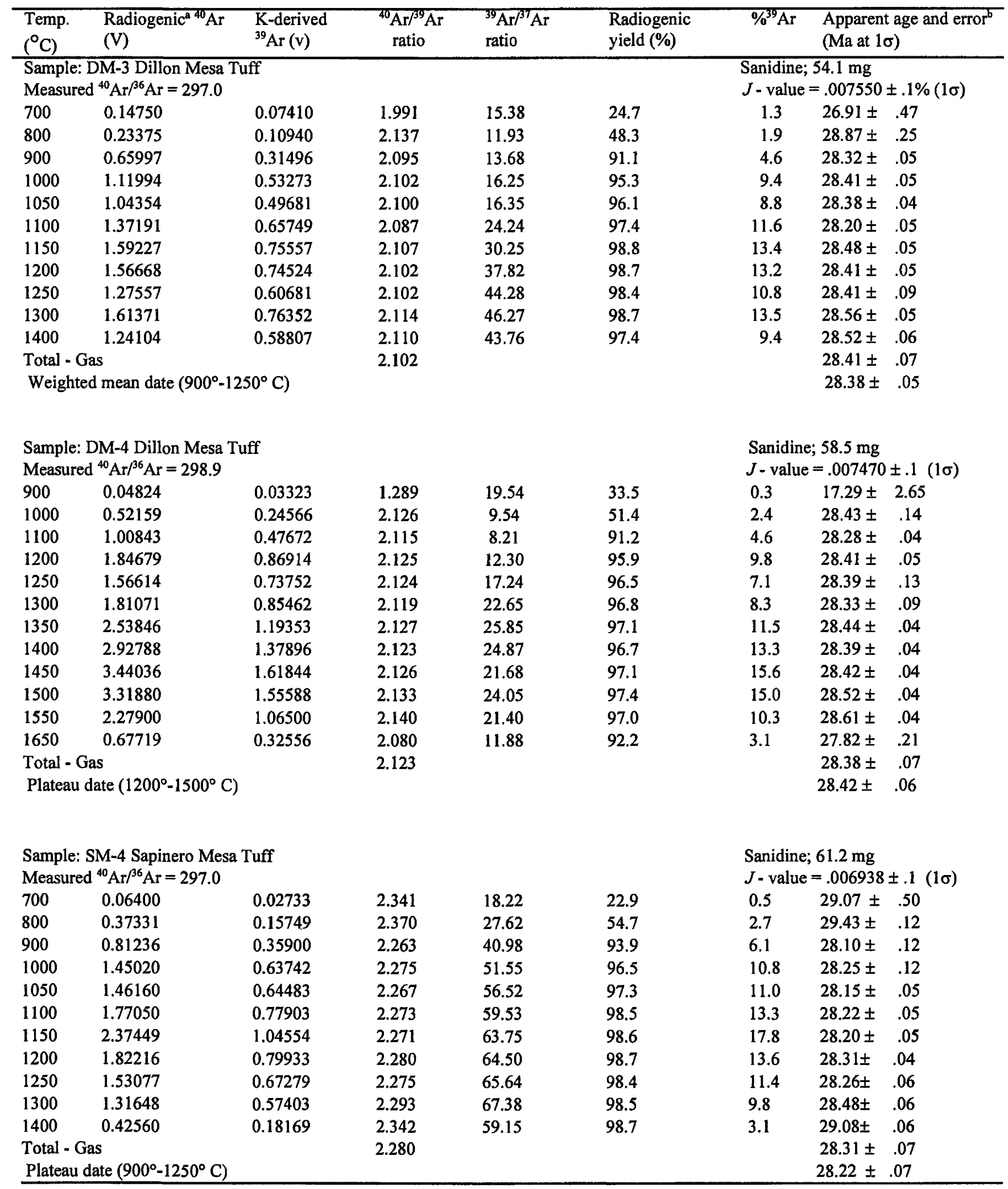


Table 4-Continued. $\quad{ }^{40} \mathrm{Ar} /{ }^{39} \mathrm{Ar}$ data for mineral separates from rocks and mineralized material from western San Juan Mountains.

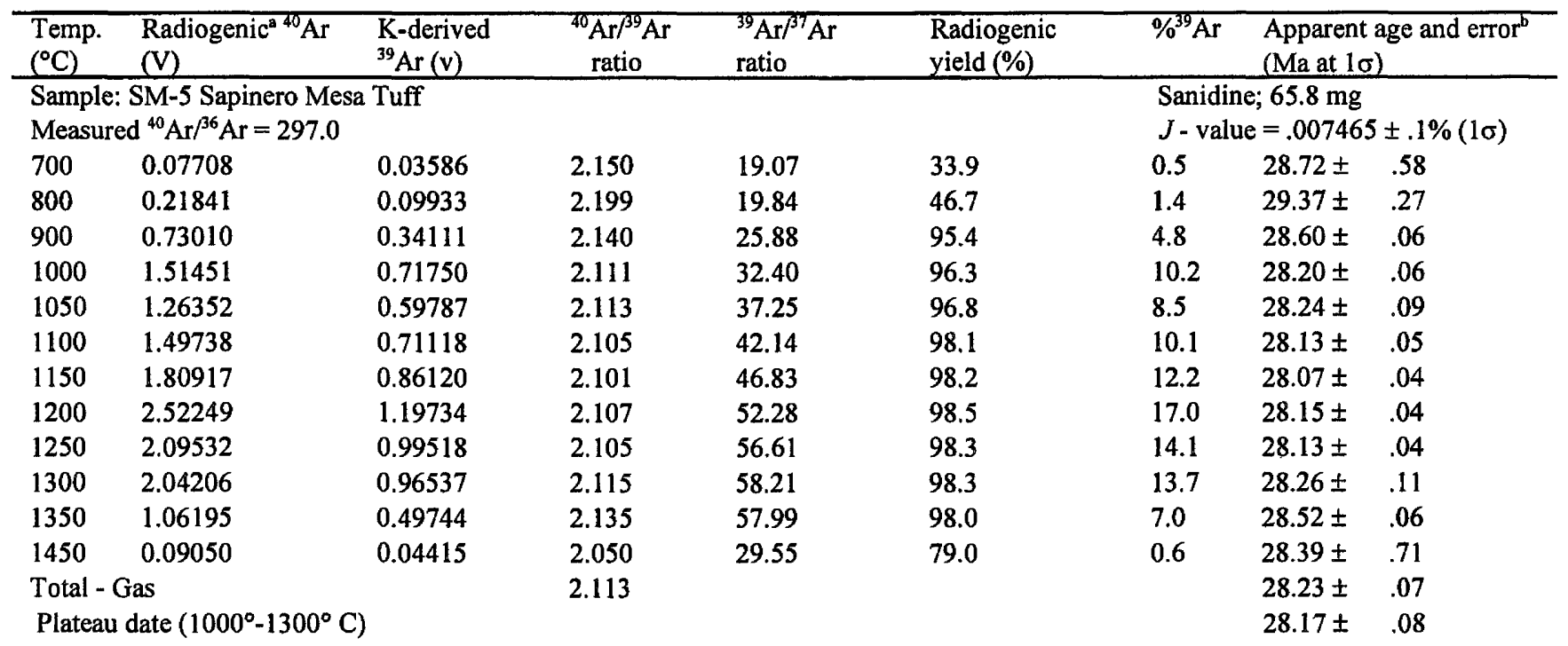

Sample: SM-6 Sapinero Mesa Tuff Measured ${ }^{40} \mathrm{Ar} /{ }^{36} \mathrm{Ar}=298.9$

$\begin{array}{cccccc}900 & 0.51454 & 0.22367 & 2.300 & 25.87 & 70.9 \\ 1000 & 1.88658 & 0.88331 & 2.136 & 19.80 & 77.0 \\ 1100 & 2.60077 & 1.24099 & 2.096 & 25.49 & 96.1 \\ 1200 & 2.74205 & 1.30962 & 2.094 & 31.38 & 96.5 \\ 1250 & 2.77353 & 1.31806 & 2.104 & 36.61 & 97.5 \\ 1300 & 2.42268 & 1.15420 & 2.099 & 38.94 & 97.4 \\ 1350 & 2.46556 & 1.17275 & 2.102 & 39.56 & 97.7 \\ 1400 & 3.40411 & 1.62027 & 2.101 & 39.57 & 97.7 \\ 1450 & 3.54420 & 1.67881 & 2.111 & 39.10 & 98.0 \\ 1500 & 2.49060 & 1.18041 & 2.110 & 37.12 & 97.5 \\ 1600 & 1.17288 & 0.55744 & 2.104 & 27.67 & 95.6\end{array}$

Plateau date $\left(1100^{\circ}-1400^{\circ} \mathrm{C}\right)$

\begin{tabular}{|c|c|c|c|c|}
\hline \multicolumn{5}{|c|}{$\begin{array}{l}\text { Sample: CL-6 Crystal Lake Tuff } \\
\text { Measured }{ }^{40} \mathrm{Ar} /{ }^{36} \mathrm{Ar}=297.0\end{array}$} \\
\hline 700 & 0.03055 & 0.01118 & 2.733 & 36.49 \\
\hline 800 & 0.25705 & 0.11088 & 2.318 & 45.36 \\
\hline 900 & 0.67206 & 0.30704 & 2.189 & 56.87 \\
\hline 1000 & 1.24321 & 0.56760 & 2.190 & 61.56 \\
\hline 1050 & 1.18334 & 0.54206 & 2.183 & 65.73 \\
\hline 1100 & 1.22996 & 0.56240 & 2.187 & 68.47 \\
\hline 1150 & 1.79874 & 0.82263 & 2.187 & 73.61 \\
\hline 1200 & 1.75943 & 0.80323 & 2.190 & 72.90 \\
\hline 1250 & 2.82580 & 1.28855 & 2.193 & 74.44 \\
\hline 1300 & 2.93237 & 1.33420 & 2.198 & 75.36 \\
\hline 1350 & 2.12447 & 0.96482 & 2.202 & 77.15 \\
\hline 1400 & 0.42564 & 0.19180 & 2.219 & 69.73 \\
\hline \multicolumn{3}{|c|}{ Total - Gas } & 2.196 & \\
\hline
\end{tabular}

\begin{tabular}{|c|c|c|}
\hline & $\begin{array}{l}\mathrm{e} ; 66.6 \mathrm{~m} \\
\mathrm{e}=.0074\end{array}$ & $\pm .1 \%(1 \sigma)$ \\
\hline 1.8 & $30.85 \pm$ & .17 \\
\hline 7.2 & $28.66 \pm$ & .10 \\
\hline 10.1 & $28.13 \pm$ & .04 \\
\hline 10.6 & $28.10 \pm$ & .04 \\
\hline 10.7 & $28.24 \pm$ & .06 \\
\hline 9.4 & $28.17 \pm$ & .04 \\
\hline 9.5 & $28.22 \pm$ & .09 \\
\hline 13.1 & $28.20 \pm$ & .04 \\
\hline 13.6 & $28.33 \pm$ & .04 \\
\hline 9.6 & $28.32 \pm$ & .06 \\
\hline 4.5 & $28.24 \pm$ & .04 \\
\hline & $28.30 \pm$ & .04 \\
\hline & $28.18 \pm$ & .05 \\
\hline
\end{tabular}

Sanidine; $73.8 \mathrm{mg}$ $J$ - value $=.007053 \pm .1 \%(1 \sigma)$

$0.1 \quad 34.44 \pm \quad 5.48$

$\begin{array}{lll}1.5 & 29.26 \pm & .34\end{array}$

$4.1 \quad 27.64 \pm \quad .14$

$\begin{array}{lll}7.6 & 27.66 \pm \quad .07\end{array}$

$8.2 \quad 27.56 \pm \quad .04$

$8.5 \quad 27.61 \pm \quad .05$

$11.0 \quad 27.61 \pm \quad .07$

$10.7 \quad 27.66 \pm \quad .06$

$17.2 \quad 27.69 \pm \quad .05$

$\begin{array}{lll}17.8 & 27.75 \pm \quad .06\end{array}$

$12.9 \quad 27.80 \pm \quad .04$

$2.6 \quad 28.02 \pm \quad .05$

$27.72 \pm \quad .07$

Plateau date $\left(900^{\circ}-1200^{\circ} \mathrm{C}\right)$ $27.62 \pm \quad .07$ 
Table 4-Continued. ${ }^{40} \mathrm{Ar} /{ }^{39} \mathrm{Ar}$ data for mineral separates from rocks and mineralized material from western San Juan Mountains.

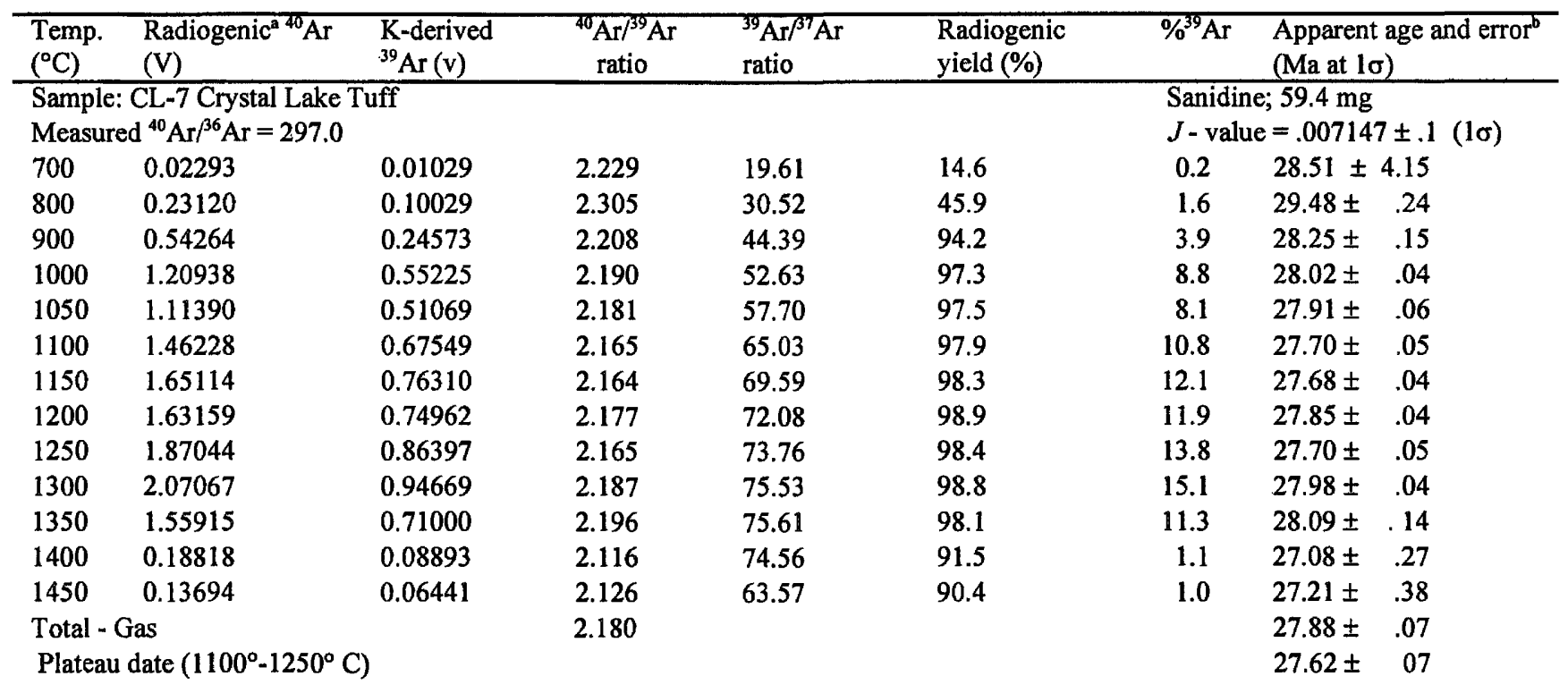

Sample: SM-1 Sultan Mountain Stock

Sanidine; $53.4 \mathrm{mg}$

Measured ${ }^{40} \mathrm{Ar} /{ }^{36} \mathrm{Ar}=298.9$

$\begin{array}{cccccc}800 & 0.22794 & 0.1224 \varepsilon & 1.861 & 26.65 & 66.3 \\ 900 & 0.10540 & 0.08493 & 1.241 & 10.08 & 52.4 \\ 1000 & 0.39958 & 0.20272 & 1.971 & 48.23 & 38.3 \\ 1100 & 1.94902 & 0.93841 & 2.074 & 150.06 & 85.5 \\ 1200 & 1.97061 & 0.94589 & 2.083 & 137.47 & 94.5 \\ 1250 & 1.32046 & 0.62991 & 2.096 & 92.59 & 94.8 \\ 1300 & 1.57494 & 0.74461 & 2.115 & 52.15 & 94.5 \\ 1350 & 2.36161 & 1.12322 & 2.103 & 57.88 & 95.6 \\ 1400 & 3.53391 & 1.70137 & 2.077 & 80.71 & 97.0 \\ 1450 & 3.45471 & 1.65910 & 2.082 & 92.34 & 97.1 \\ 1550 & 1.31994 & 0.62770 & 2.103 & 15.45 & 96.7 \\ \text { Total - Gas } & & 2.075 & & \end{array}$

$J$ - value $=.007098 \pm .1(1 \sigma)$

$1.4 \quad 23.67 \pm \quad .45$

$\begin{array}{lll}1.0 & 15.82 \pm \quad .72\end{array}$

$2.3 \quad 25.06 \pm \quad .13$

$10.7 \quad 26.36 \pm \quad .04$

$10.8 \quad 26.48 \pm \quad .05$

$7.2 \quad 26.64 \pm \quad .04$

$8.5 \quad 26.88 \pm \quad .06$

$12.8 \quad 26.72 \pm \quad .04$

$19.426 .40 \pm .04$

$18.9 \quad 26.47 \pm \quad .04$

$7.1 \quad 26.73 \pm \quad .04$

$26.37 \pm \quad .06$

$26.56 \pm .04$

Sample: SM-2 Sultan Mountain Stock

Measured ${ }^{40} \mathrm{Ar} /{ }^{36} \mathrm{Ar}=298.9$

$\begin{array}{ccccc}800 & 0.88567 & 0.46229 & 1.916 & 38.12 \\ 900 & 0.24570 & 0.12794 & 1.920 & 38.45 \\ 950 & 0.18006 & 0.09076 & 1.984 & 39.68 \\ 1000 & 0.48369 & 0.24300 & 1.991 & 52.84 \\ 1100 & 1.43960 & 0.71790 & 2.005 & 58.02 \\ 1150 & 1.02607 & 0.51668 & 1.986 & 89.81 \\ 1200 & 1.32755 & 0.65887 & 2.015 & 90.98 \\ 1250 & 1.24586 & 0.62722 & 1.986 & 83.32 \\ 1300 & 1.38120 & 0.70244 & 1.966 & 74.27 \\ 1350 & 1.34623 & 1.68894 & 1.981 & 77.23 \\ 1400 & 2.88092 & 1.46493 & 1.967 & 84.96 \\ 1450 & 1.4704 & 0.71099 & 1.979 & 62.59 \\ 1550 & 0.42435 & 0.21713 & 1.954 & 10.60 \\ \text { Total }- \text { Gas } & & 1.978 & \end{array}$

84.3

62.7

29.2

85.5

93.4

93.8

95.5

94.7

94.1

95.7

95.2

95.0

87.3
Biotite; $47.8 \mathrm{mg}$

$J$ - value $=.007543 \pm .1 \%(1 \sigma)$

$5.6 \quad 25.88 \pm .13$

$1.6 \quad 25.94 \pm .21$

$1.1 \quad 26.80 \pm .54$

$3.0 \quad 26.88 \pm .28$

$8.7 \quad 27.08 \pm .04$

$6.3 \quad 26.82 \pm .10$

$8.0 \quad 27.21 \pm .04$

$7.6 \quad 26.83 \pm .08$

$8.526 .56 \pm .05$

$20.5 \quad 26.76 \pm \quad .04$

$17.8 \quad 26.56 \pm .04$

$8.6 \quad 26.73 \pm .04$

$2.6 \quad 26.40 \pm .05$

$26.71 \pm .07$

$26.66 \pm .06$ 
Table 4-Continued. ${ }^{40} \mathrm{Ar} /{ }^{39} \mathrm{Ar}$ data for mineral separates from rocks and mineralized material from western San Juan Mountains.

\begin{tabular}{|c|c|c|c|c|c|c|c|}
\hline $\begin{array}{l}\text { Temp. } \\
\left({ }^{\circ} \mathrm{C}\right)\end{array}$ & $\begin{array}{l}\text { Radiogenic }{ }^{40} \mathrm{Ar} \\
\text { (V) }\end{array}$ & $\begin{array}{l}\text { K-derived } \\
{ }^{39} \mathrm{Ar}(\mathrm{v})\end{array}$ & $\begin{array}{l}{ }^{40} \mathrm{Ar} /{ }^{39} \mathrm{Ar} \\
\text { ratio }\end{array}$ & $\begin{array}{l}{ }^{39} \mathrm{Ar}{ }^{37} \mathrm{Ar} \\
\text { ratio }\end{array}$ & $\begin{array}{l}\text { Radiogenic } \\
\text { yield (\%) }\end{array}$ & $\%{ }^{39} \mathrm{Ar}$ & $\begin{array}{l}\text { Apparent age and error } \\
(\text { Ma at } 1 \sigma)\end{array}$ \\
\hline \multirow{2}{*}{\multicolumn{6}{|c|}{$\begin{array}{l}\text { Sample: } \mathrm{MP}-8 \\
\text { Measured }{ }^{40} \mathrm{Ar} /{ }^{36} \mathrm{Ar}=296.6\end{array}$}} & \multirow{2}{*}{\multicolumn{2}{|c|}{$\begin{array}{l}\text { Biotite; } 96.6 \mathrm{mg} \\
J \text { - value }=.007299 \pm .1 \%(1 \sigma)\end{array}$}} \\
\hline & & & & & & & \\
\hline 650 & 0.05293 & 0.04122 & 1.284 & n.d. ${ }^{\mathrm{c}}$ & 13.3 & 0.9 & $16.83 \pm .58$ \\
\hline 750 & 0.68721 & 0.33905 & 2.027 & n.d. & 52.1 & 7.3 & $26.49 \pm .13$ \\
\hline 850 & 3.50545 & 1.74244 & 2.012 & n.d. & 87.4 & 37.3 & $26.30 \pm .05$ \\
\hline 950 & 1.46535 & 0.72520 & 2.021 & n.d. & 93.8 & 15.5 & $26.41 \pm .08$ \\
\hline 1000 & 0.48788 & 0.23879 & 2.043 & n.d. & 90.2 & 5.1 & $26.70 \pm .08$ \\
\hline 1050 & 0.71651 & 0.35380 & 2.025 & n.d. & 90.7 & 7.6 & $26.47 \pm .17$ \\
\hline 1150 & 1.49848 & 0.73782 & 2.031 & n.d. & 92.9 & 15.8 & $26.55 \pm .09$ \\
\hline 1350 & 1.03653 & 0.48897 & 2.120 & n.d. & 90.1 & 10.5 & $27.70 \pm .05$ \\
\hline \multirow{2}{*}{\multicolumn{3}{|c|}{$\begin{array}{l}\text { Total - Gas } \\
\text { Plateau date }\left(750^{\circ}-1050^{\circ} \mathrm{C}\right)\end{array}$}} & 2.025 & & & & $26.47 \pm .08$ \\
\hline & & & & & & & $26.39 \pm \quad .10$ \\
\hline \multicolumn{6}{|c|}{$\begin{array}{l}\text { Sample: UPL-1 Uncompahgre Peak Volcanics } \\
\text { Measured }{ }^{40} \mathrm{Ar} /{ }^{36} \mathrm{Ar}=298.9\end{array}$} & \multicolumn{2}{|c|}{$\begin{array}{l}\text { Sanidine; } 53.4 \mathrm{mg} \\
J-\text { value }=.007098 \pm .1(1 \sigma)\end{array}$} \\
\hline 700 & 0.01409 & 0.00653 & 1.607 & 10.50 & 29.4 & 0.1 & $20.80 \pm \quad 6.52$ \\
\hline 800 & 0.03111 & 0.01108 & 2.809 & 12.98 & 81.5 & 0.1 & $36.20 \pm \quad 3.07$ \\
\hline 900 & 0.09703 & 0.05077 & 1.911 & 20.43 & 68.4 & 0.4 & $24.71 \pm \quad 1.31$ \\
\hline 1000 & 0.28699 & 0.13937 & 2.059 & 20.12 & 43.7 & 1.2 & $26.61 \pm .27$ \\
\hline 1100 & 0.78449 & 0.39326 & 1.995 & 21.12 & 83.1 & 3.3 & $25.79 \pm \quad .05$ \\
\hline 1200 & 1.52569 & .077394 & 1.971 & 23.24 & 95.3 & 6.5 & $25.48 \pm \quad .05$ \\
\hline 1250 & 1.56426 & 0.79407 & 1.970 & 26.84 & 96.0 & 6.6 & $25.47 \pm \quad .04$ \\
\hline 1300 & 1.84449 & 0.93184 & 1.979 & 33.53 & 96.8 & 7.8 & $25.59 \pm \quad .05$ \\
\hline 1350 & 2.61909 & 1.32197 & 1.981 & 42.32 & 97.2 & 11.1 & $25.61 \pm .05$ \\
\hline 1400 & 1.55860 & 0.78766 & 1.979 & 49.30 & 97.6 & 6.6 & $25.58 \pm \quad .04$ \\
\hline 1450 & 4.57149 & 2.30020 & 1.987 & $55.6^{\circ}$ & 98.1 & 19.2 & $25.69 \pm \quad .04$ \\
\hline 1500 & 3.14272 & 1.58420 & 1.984 & 59.97 & 98.1 & 13.3 & $25.64 \pm \quad .04$ \\
\hline 1550 & 4.38158 & 2.20231 & 1.990 & 62.46 & 98.3 & 18.4 & $25.72 \pm \quad .04$ \\
\hline 1650 & 1.31119 & 0.65481 & 2.002 & 31.90 & 96.9 & 5.5 & $25.88 \pm \quad .06$ \\
\hline \multirow{2}{*}{\multicolumn{3}{|c|}{$\begin{array}{l}\text { Total - Gas } \\
\text { Plateau date }\left(1300^{\circ}-1500^{\circ} \mathrm{C}\right)\end{array}$}} & 1.985 & & & & $25.67 \pm \quad .06$ \\
\hline & & & & & & & $25.63 \pm \quad .04$ \\
\hline \multicolumn{6}{|c|}{$\begin{array}{l}\text { Sample: UHT-10 Ute-Hidden Treasure vein } \\
\text { Measured }{ }^{40} \mathrm{Ar}{ }^{\beta 6} \mathrm{Ar}=298.9\end{array}$} & \multicolumn{2}{|c|}{$\begin{array}{l}\text { Sericite; } 96.6 \mathrm{mg} \\
J \text {-value }=.006248 \pm .1 \%(1 \sigma)\end{array}$} \\
\hline 400 & 1.54336 & 0.75315 & 2.049 & 268.56 & 85.6 & 7.5 & $22.95 \pm .12$ \\
\hline 500 & 1.17534 & 0.57671 & 2.038 & 186.52 & 93.0 & 5.7 & $22.83 \pm \quad .13$ \\
\hline 600 & 4.91006 & 2.21342 & 2.218 & 296.88 & 98.3 & 21.9 & $24.83 \pm \quad .04$ \\
\hline 650 & 7.82130 & 3.34640 & 2.337 & 311.82 & 98.6 & 33.1 & $26.15 \pm \quad .04$ \\
\hline 700 & 5.29088 & 2.24264 & 2.359 & 384.27 & 92.8 & 22.2 & $26.40 \pm \quad .04$ \\
\hline 750 & 1.76903 & 0.75854 & 2.332 & 392.02 & 93.8 & 7.5 & $26.10 \pm \quad .04$ \\
\hline 800 & 0.41276 & 0.17310 & 2.385 & 222.06 & 88.8 & 1.7 & $26.68 \pm \quad .29$ \\
\hline 900 & 0.05887 & 0.02679 & 2.198 & 41.74 & 39.1 & 0.3 & $24.60 \pm \quad .84$ \\
\hline 1000 & 0.03890 & 0.00696 & 5.590 & 4.23 & 18.3 & 0.1 & $61.94 \pm 13.26$ \\
\hline \multicolumn{3}{|c|}{ Total - Gas } & 2.280 & & & & $25.51 \pm .06$ \\
\hline
\end{tabular}


Table 4-Continued. $\quad{ }^{40} \mathrm{Ar} /{ }^{39} \mathrm{Ar}$ data for mineral separates from rocks and mineralized material from western San Juan Mountains.

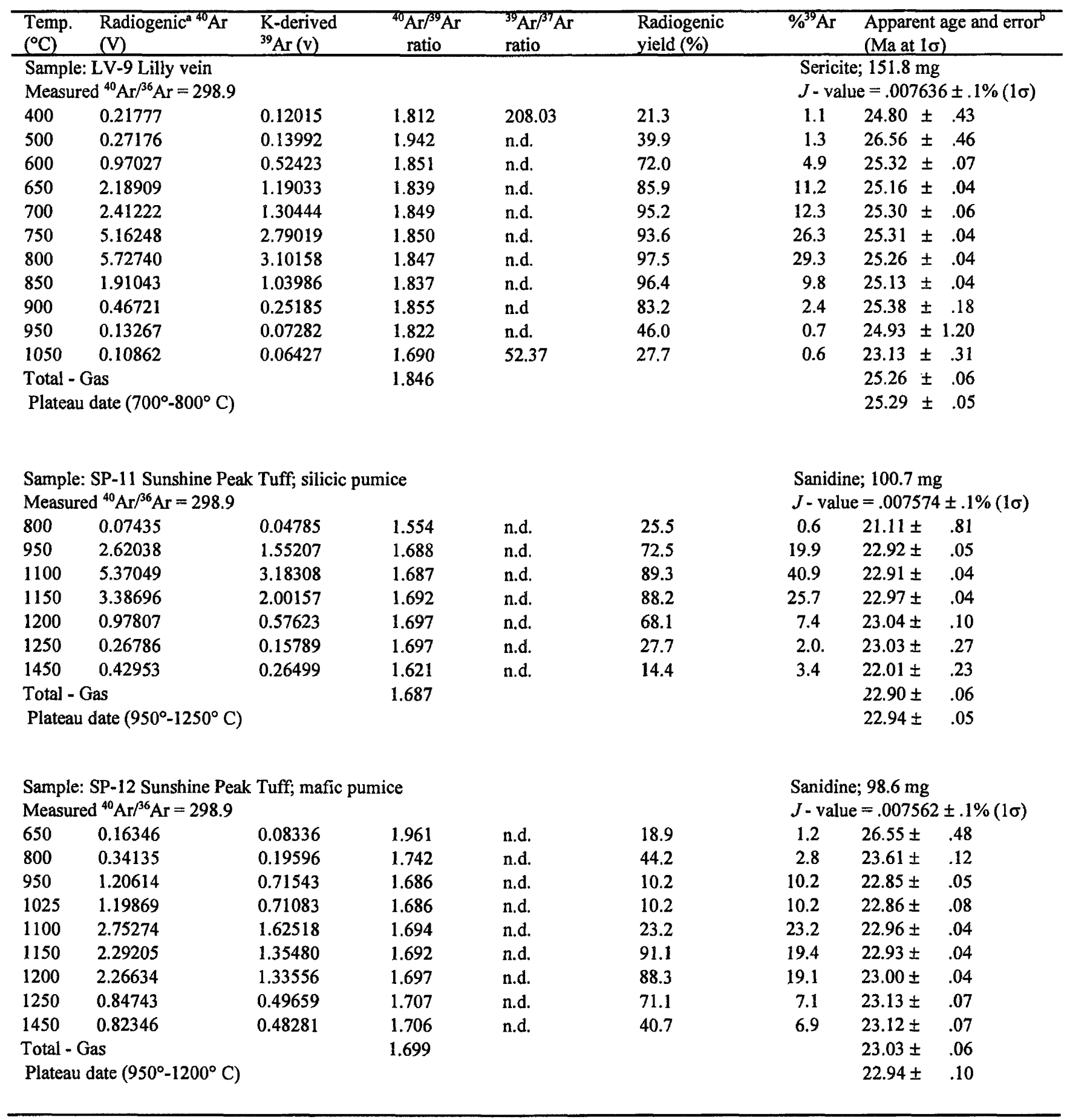


Table 4-Continued. ${ }^{40} \mathrm{Ar} /{ }^{39} \mathrm{Ar}$ data for mineral separates from rocks and mineralized material from western San Juan Mountains.

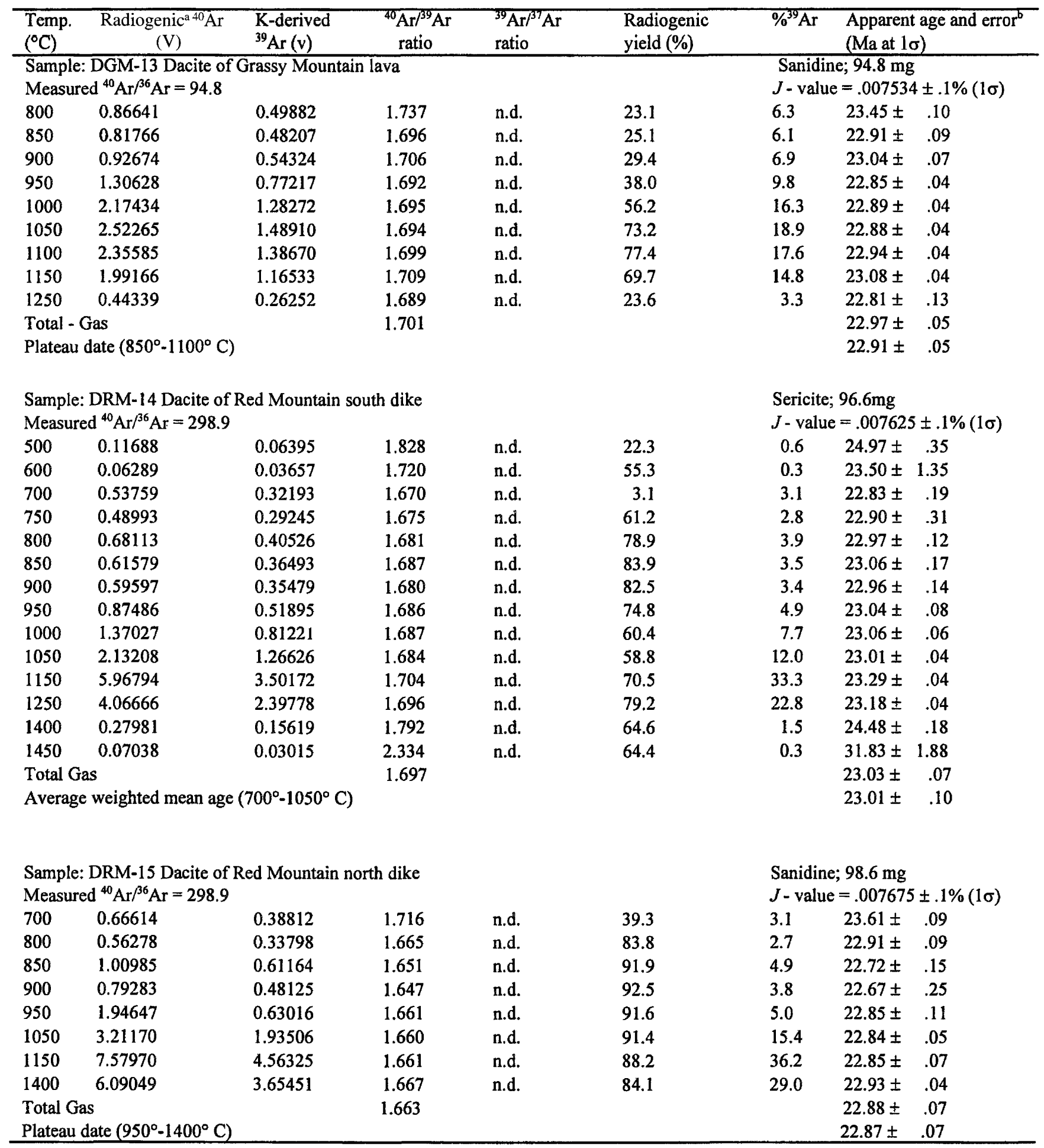


Table 4-Continued. ${ }^{40} \mathrm{Ar} /{ }^{39} \mathrm{Ar}$ data for mineral separates from rocks and mineralized material from western San Juan Mountains.

\begin{tabular}{|c|c|c|c|c|c|c|c|}
\hline $\begin{array}{l}\text { Temp. } \\
\left({ }^{\circ} \mathrm{C}\right)\end{array}$ & $\begin{array}{l}\text { Radiogenic }{ }^{240} \mathrm{Ar} \\
\text { (V) }\end{array}$ & $\begin{array}{l}\text { K-derived } \\
{ }^{39} \mathrm{Ar}(\mathrm{v})\end{array}$ & $\begin{array}{l}{ }^{40} \mathrm{Ar} /{ }^{99} \mathrm{Ar} \\
\text { ratio }\end{array}$ & $\begin{array}{l}{ }^{39} \mathrm{Ar} /{ }^{37} \mathrm{Ar} \\
\text { ratio }\end{array}$ & $\begin{array}{l}\text { Radiogenic } \\
\text { yield }(\%)\end{array}$ & $\%{ }^{39} \mathrm{Ar}$ & $\begin{array}{l}\text { Apparent age and error }{ }^{b} \\
(\mathrm{Ma} \text { at } \mathrm{l} \sigma \text { ) }\end{array}$ \\
\hline \multicolumn{6}{|c|}{ Measured ${ }^{40} \mathrm{Ar} /{ }^{36} \mathrm{Ar}=298.9$} & \multicolumn{2}{|c|}{$J-$ value $=.007557 \pm .1 \%(1 \sigma)$} \\
\hline 800 & 1.11923 & 0.63868 & 1.752 & n.d. & 57.6 & 8.7 & $23.73 \pm .05$ \\
\hline 850 & 0.90892 & 0.54107 & 1.680 & n.d. & 88.7 & 7.4 & $22.76 \pm .11$ \\
\hline 1000 & 1.50515 & 0.89791 & 1.676 & n.d. & 91.0 & 12.3 & $22.71 \pm .04$ \\
\hline 1050 & 1.56763 & 0.92980 & 1.686 & n.d. & 88.5 & 12.7 & $22.84 \pm .05$ \\
\hline 1100 & 2.00859 & 1.19461 & 1.681 & n.d. & 80.8 & 16.3 & $22.78 \pm .04$ \\
\hline 1150 & 2.59668 & 1.53820 & 1.688 & n.d. & 78.9 & 21.0 & $22.87 \pm .04$ \\
\hline 1250 & 0.55580 & 0.32353 & 1.718 & n.d. & 68.4 & 4.4 & $23.27 \pm .12$ \\
\hline
\end{tabular}

Sample: DRM-17 Dacite of Red Mountain post-alunite dike Measured ${ }^{40} \mathrm{Ar} /{ }^{36} \mathrm{Ar}=298.9$

$\begin{array}{lrrrrr}500 & 0.02774 & 0.01763 & 1.573 & \text { n.d. } & 3.7 \\ 600 & 0.04282 & 0.02669 & 1.604 & \text { n.d. } & 10.2 \\ 650 & 0.04106 & 0.02137 & 1.921 & \text { n.d. } & 17.9 \\ 700 & 0.06525 & 0.02598 & 2.512 & \text { n.d. } & 15.5 \\ 750 & 0.15741 & 0.07412 & 2.124 & \text { n.d. } & 26.4 \\ 800 & 0.40456 & 0.21452 & 1.886 & \text { n.d. } & 45.5 \\ 850 & 0.93166 & 0.53000 & 1.758 & \text { n.d. } & 67.2 \\ 900 & 0.84302 & 0.47765 & 1.765 & \text { n.d. } & 82.3 \\ 950 & 1.12973 & 0.64564 & 1.750 & \text { n.d. } & 85.5 \\ 1000 & 1.28113 & 0.74263 & 1.725 & \text { n.d. } & 76.8 \\ 1050 & 2.48423 & 1.45273 & 1.710 & \text { n.d. } & 73.7 \\ 1150 & 4.12228 & 2.41476 & 1.707 & \text { n.d. } & 73.6 \\ 1300 & 0.53857 & 0.30793 & 1.749 & \text { n.d. } & 80.2 \\ \text { Total Gas } & & & 1.736 & & \end{array}$

Plateau age $\left(1050^{\circ}-1150^{\circ} \mathrm{C}\right)$

Sample: CA-18 Coarse-grained vein alunite; Red Mountain Measured ${ }^{40} \mathrm{Ar} /{ }^{36} \mathrm{Ar}=298.9$

\begin{tabular}{lllllr}
400 & 0.07126 & 0.03875 & 1.839 & n.d. & 7.8 \\
450 & 0.01255 & 0.00680 & 1.844 & n.d. & 14.1 \\
500 & 0.03620 & 0.02183 & 1.659 & n.d. & 50.4 \\
600 & 3.11894 & 1.83436 & 1.700 & n.d. & 79.8 \\
650 & 6.82897 & 3.94701 & 1.730 & n.d. & 51.7 \\
700 & 6.10068 & 3.53057 & 1.728 & n.d. & 52.1 \\
750 & 0.26300 & 0.12615 & 2.085 & n.d. & 8.4 \\
800 & 0.02004 & 0.00381 & 5.265 & n.d. & 2.7 \\
Total Gas & & 1.730 & & \\
Plateau age $\left(650^{\circ}-700^{\circ} \mathrm{C}\right)$ & & & & \\
\hline
\end{tabular}

Biotite; $88 \mathrm{mg}$

$$
\begin{array}{cc}
J \text { - value }=.00759 \pm .1 \%(1 \sigma) \\
0.3 & 21.41 \pm 2.78 \\
0.4 & 21.83 \pm 2.21 \\
0.3 & 26.11 \pm 2.22 \\
0.4 & 34.07 \pm 1.88 \\
1.1 & 28.85 \pm .71 \\
3.1 & 25.64 \pm .21 \\
7.6 & 23.91 \pm .08 \\
6.9 & 24.01 \pm .09 \\
9.3 & 23.80 \pm .13 \\
10.7 & 23.47 \pm .05 \\
20.9 & 23.26 \pm .04 \\
34.7 & 23.22 \pm .04 \\
4.4 & 23.79 \pm .23 \\
& 23.62 \pm .10 \\
& 23.24 \pm .04
\end{array}
$$

\begin{tabular}{cc}
\multicolumn{3}{c}{ Alunite; $108 \mathrm{mg}$} \\
$J$ - value $=.007455 \pm .1 \%(1 \sigma)$ \\
0.4 & $24.56 \pm 2.28$ \\
0.1 & $24.63 \pm 7.33$ \\
0.2 & $22.17 \pm 1.64$ \\
19.3 & $22.72 \pm .04$ \\
41.5 & $23.12 \pm .04$ \\
37.1 & $23.09 \pm .04$ \\
1.3 & $27.82 \pm .27$ \\
0.0 & $69.45 \pm 11.87$ \\
& $23.12 \pm .06$ \\
& $23.11 \pm .04$
\end{tabular}


Table 4-Continued. ${ }^{40} \mathrm{Ar} /{ }^{39} \mathrm{Ar}$ data for mineral separates from rocks and mineralized material from western San Juan Mountains.

\begin{tabular}{|c|c|c|c|c|c|c|c|}
\hline $\begin{array}{l}\text { Temp. } \\
\left({ }^{\circ} \mathrm{C}\right)\end{array}$ & $\begin{array}{l}\text { Radiogenic }{ }^{240} \mathrm{Ar} \\
\text { (V) }\end{array}$ & $\begin{array}{l}\text { K-derived } \\
{ }^{39} \mathrm{Ar}(\mathrm{v})\end{array}$ & $\begin{array}{l}{ }^{40} \mathrm{Ar} /{ }^{39} \mathrm{Ar} \\
\text { ratio }\end{array}$ & ${ }^{39} \mathrm{Ar} /{ }^{37} \mathrm{Ar}$ ratio & $\begin{array}{l}\text { Radiogenic } \\
\text { yield (\%) }\end{array}$ & $\%{ }^{39} \mathrm{Ar}$ & $\begin{array}{l}\text { Apparent age and error } \\
\text { (Ma at } 1 \sigma \text { ) }\end{array}$ \\
\hline \multirow{2}{*}{\multicolumn{6}{|c|}{$\begin{array}{l}\text { Sample: BWV-19 Black Wonder vein } \\
\text { Measured }{ }^{40} \mathrm{Ar} /{ }^{36} \mathrm{Ar}=298.9\end{array}$}} & \multicolumn{2}{|c|}{ Adularia; $134 \mathrm{mg}$} \\
\hline & & & & & & \multicolumn{2}{|c|}{$J$-value $=.007341 \pm .1 \%(1 \sigma)$} \\
\hline 500 & 0.10627 & 0.05281 & 2.012 & 74.81 & 7.4 & 0.2 & $26.46 \pm .35$ \\
\hline 600 & 0.17164 & 0.12173 & 1.410 & 93.23 & 22.0 & 0.4 & $18.58 \pm .31$ \\
\hline 650 & 0.31946 & 0.24091 & 1.326 & 21.49 & 40.1 & 0.7 & $17.48 \pm .19$ \\
\hline 700 & 0.44707 & 0.35307 & 1.266 & 15.07 & 42.3 & 1.1 & $16.69 \pm .06$ \\
\hline 750 & 0.53482 & 0.42204 & 1.267 & 63.86 & 48.4 & 1.3 & $16.70 \pm .03$ \\
\hline 800 & 1.05704 & 0.84149 & 1.256 & n.d. & 81.1 & 3.6 & $16.56 \pm .04$ \\
\hline 850 & 1.09813 & 0.87470 & 1.255 & n.d. & 89.2 & 3.7 & $16.55 \pm .04$ \\
\hline 900 & 1.62924 & 1.30016 & 1.253 & n.d. & 93.1 & 4.0 & $16.52 \pm .03$ \\
\hline 950 & 2.37365 & 1.89530 & 1.252 & n.d. & 92.9 & 5.8 & $16.51 \pm .03$ \\
\hline 1000 & 2.28044 & 1.81954 & 1.253 & n.d. & 87.9 & 0.5 & $16.52 \pm .03$ \\
\hline 1050 & 2.69076 & 2.14736 & 1.253 & n.d. & 88.3 & 6.5 & $16.52 \pm .03$ \\
\hline 1100 & 2.63784 & 2.10314 & 1.254 & n.d. & 89.0 & 6.4 & $16.53 \pm .03$ \\
\hline 1150 & 2.91681 & 2.32595 & 1.254 & n.d. & 86.5 & 7.1 & $16.53 \pm .03$ \\
\hline 1200 & 3.03192 & 2.41245 & 1.257 & n.d. & 74.5 & 10.3 & $16.57 \pm .03$ \\
\hline 1250 & 6.45907 & 5.12884 & 1.259 & n.d. & 64.2 & 15.6 & $16.60 \pm .03$ \\
\hline 1300 & 12.12783 & 9.56362 & 1.268 & n.d. & 62.5 & 25.1 & $16.72 \pm .03$ \\
\hline 1350 & 1.36364 & 1.04195 & 1.309 & n.d. & 53.7 & 3.2 & $17.25 \pm .04$ \\
\hline 1400 & 0.16648 & 0.12667 & 1.314 & n.d. & 51.5 & 0.4 & $17.32 \pm .11$ \\
\hline 1450 & 0.07849 & 0.06090 & 1.289 & n.d. & 47.2 & 0.2 & $16.99 \pm .33$ \\
\hline \multicolumn{3}{|c|}{ Total Gas } & 1.264 & & & & $16.66 \pm .03$ \\
\hline \multicolumn{3}{|c|}{ Plateau date $\left(800^{\circ}-1200^{\circ} \mathrm{C}\right)$} & & & & & $16.52 \pm .03$ \\
\hline
\end{tabular}

${ }^{\mathrm{a}}{ }^{40} \mathrm{Ar}_{\mathrm{R}} /{ }^{39} \mathrm{Ar}_{\mathrm{K}}$ has been corrected for all interfering isotopes including atmospheric argon. The measured production ratios for samples SP11, SP-12, DGM-13, DRM-14, DRM-15, DRM-16, DRM-17, and CA-18 $\operatorname{are~}\left({ }^{40} \mathrm{Ar} /{ }^{39} \mathrm{Ar}\right)_{\mathrm{K}}=8.70 \times 10^{-3},\left({ }^{88} \mathrm{Ar}{ }^{39} \mathrm{Ar}\right)_{\mathrm{K}}=1.310 \times 10^{-2}$, $\left({ }^{37} \mathrm{Ar}{ }^{\beta 9} \mathrm{Ar}\right)_{\mathrm{K}}=1.11 \times 10^{-4},\left({ }^{36} \mathrm{Ar}{ }^{\beta 7} \mathrm{Ar}\right)_{\mathrm{Ca}}=2.69 \times 10^{-4},\left({ }^{39} \mathrm{Ar} /{ }^{37} \mathrm{Ar}\right)_{\mathrm{Ca}}=6.55 \times 10^{-4}$, and $\left({ }^{38} \mathrm{Ar}{ }^{37} \mathrm{Ar}\right)_{\mathrm{Ca}}=3.50 \times 10^{-5}$. The measured production ratios for sample UHT-10 are $\left({ }^{40} \mathrm{Ar}{ }^{\beta 9} \mathrm{Ar}\right)_{\mathrm{K}}=1.01 \times 10^{-2},\left({ }^{38} \mathrm{Ar}{ }^{\beta 9} \mathrm{Ar}\right)_{\mathrm{K}}=1.310 \times 10^{-2},\left({ }^{37} \mathrm{Ar}{ }^{\beta 9} \mathrm{Ar}\right)_{\mathrm{K}}=2.35 \times 10^{-4},\left({ }^{36} \mathrm{Ar}{ }^{\beta 7} \mathrm{Ar}\right)_{\mathrm{Ca}}=2.70 \times 10^{-4}$, $\left({ }^{39} \mathrm{Ar}{ }^{37} \mathrm{Ar}\right)_{\mathrm{C}_{\mathrm{a}}}=6.48 \times 10^{-4}$, and $\left({ }^{38} \mathrm{Ar}{ }^{37} \mathrm{Ar}\right)_{\mathrm{C}_{\mathrm{a}}}=3.70 \times 10^{-5}$. The measured production ratios for samples MP-8 and LV-9 are $\left({ }^{40} \mathrm{Ar} /{ }^{39} \mathrm{Ar}\right)_{\mathrm{K}}=9.184 \times 10^{-3},\left({ }^{38} \mathrm{Ar} /{ }^{39} \mathrm{Ar}\right)_{\mathrm{K}}=1.306 \times 10^{-2},\left({ }^{37} \mathrm{Ar} /{ }^{39} \mathrm{Ar}\right)_{\mathrm{K}}=8.20 \times 10^{-5},\left({ }^{36} \mathrm{Ar} /{ }^{37} \mathrm{Ar}\right)_{\mathrm{Ca}}=2.70 \times 10^{-4},\left({ }^{39} \mathrm{Ar} /{ }^{37} \mathrm{Ar}\right)_{\mathrm{Ca}}=6.36 \times 10^{-4}$, and $\left({ }^{38} \mathrm{Ar} /{ }^{37} \mathrm{Ar}\right)_{\mathrm{Ca}}=3.17 \times 10^{-5}$. The measured production ratios for sample $\mathrm{BWV}-19$ are $\left({ }^{40} \mathrm{Ar} /{ }^{39} \mathrm{Ar}\right)_{\mathrm{K}}=7.950 \times 10^{-3},\left({ }^{38} \mathrm{Ar} /{ }^{39} \mathrm{Ar}\right)_{\mathrm{K}}=1.308 \times 10^{-2}$, $\left({ }^{37} \mathrm{Ar}{ }^{39} \mathrm{Ar}\right)_{\mathrm{K}}=1.50 \times 10^{-4},\left({ }^{36} \mathrm{Ar} /{ }^{37} \mathrm{Ar}\right)_{\mathrm{Ca}}=2.66 \times 10^{-4},\left({ }^{39} \mathrm{Ar} /{ }^{37} \mathrm{Ar}\right)_{\mathrm{Ca}}=6.35 \times 10^{-4}$, and $\left({ }^{38} \mathrm{Ar}{ }^{37} \mathrm{Ar}\right)_{\mathrm{Ca}}=4.50 \times 10^{-5}$. The measured production ratios for samples UR-1, BM-2, BM-3, DM-3, DM-4, SM-1, SM-2, UPL-1, SM-4, SM-5, SM-6, CL-6, and CL-7 are $\left({ }^{40} \mathrm{Ar}{ }^{\beta 9} \mathrm{Ar}\right)_{\mathrm{K}}=9.350 \times 10^{-3}$, $\left({ }^{38} \mathrm{Ar} /{ }^{39} \mathrm{Ar}\right)_{\mathrm{K}}=1.304 \times 10^{-2},\left({ }^{37} \mathrm{Ar} /{ }^{39} \mathrm{Ar}\right)_{\mathrm{K}}=3.0 \times 10^{-4},\left({ }^{36} \mathrm{Ar} /{ }^{37} \mathrm{Ar}\right)_{\mathrm{Ca}}=2.70 \times 10^{-4},\left({ }^{39} \mathrm{Ar} /{ }^{37} \mathrm{Ar}\right)_{\mathrm{Ca}}=7.20 \times 10^{-4}$, and $\left({ }^{38} \mathrm{Ar} /{ }^{37} \mathrm{Ar}\right)_{\mathrm{Ca}}=4.70 \times 10^{-5}$. Irradiation of each group of samples was for 30 hours at 1 megawatt in the TRIGA reactor at the U.S. Geological Survey, Denver, Colo.

${ }^{b} 1 \sigma$ error.

${ }^{c}$ n.d. not determined. 
Table 5. K-Ar analytical data for rhyolitic rocks in Lake City area.

[Analytical details are in Hon and Mehnert (1983). Map figure number locations are shown in figure 2A]

\begin{tabular}{|c|c|c|c|c|c|c|c|c|}
\hline $\begin{array}{l}\text { Map } \\
\text { Figure No. }\end{array}$ & $\begin{array}{l}\text { Sample } \\
\text { description }\end{array}$ & Field No. & Mineral & $\mathrm{Na}_{2} \mathrm{O} \%$ & $\mathrm{~K}_{2} \mathrm{O} \%$ & $\begin{array}{l}*^{40} \operatorname{Ar}\left(10^{-10}\right. \\
\text { moles/gram })\end{array}$ & $\%{ }^{40} \mathrm{Ar}$ & $\begin{array}{l}\text { Age } \mathrm{Ma} \\
\pm 1 \sigma\end{array}$ \\
\hline 26 & $\begin{array}{l}\text { Dolly Varden } \\
\text { (Rhyolite } \\
\text { vitrophyre) }\end{array}$ & $80 \mathrm{~L}-106 \mathrm{~A}$ & Biotite & $0.59,0.58$ & $9.14,9.12$ & 2.464 & 71.1 & $18.7 \pm 0.4$ \\
\hline 27 & $\begin{array}{l}\text { Mary Alice } \\
\text { Creek (Rhyolite } \\
\text { vitrophyre) }\end{array}$ & 1-6-1D & Biotite & $0.58,0.57$ & $8.92,8.89$ & 2.423 & 70.1 & $18.8 \pm 0.4$ \\
\hline 28 & $\begin{array}{l}\text { Broken Hill Sill } \\
\text { (Rhyolite } \\
\text { vitrophrye) }\end{array}$ & $80 \mathrm{~L}-103$ & Biotite & $0.56,0.54$ & $9.12,9.20$ & 2.510 & 62.5 & $18.9 \pm 0.4$ \\
\hline 29 & $\begin{array}{l}\text { Nellie Creek } \\
\text { (Rhyolite } \\
\text { vitrophyre) }\end{array}$ & $80 \mathrm{~L}-111 \mathrm{~A}$ & Biotite & $0.63,0.65$ & $8.71,8.70$ & 2.353 & 65.9 & $18.7 \pm 0.4$ \\
\hline 30 & $\begin{array}{l}\text { Larson Creek } \\
\text { (Rhyolite } \\
\text { felsite) }\end{array}$ & $80 \mathrm{~L}-110$ & Biotite & $0.57,0.57$ & $9.09,9.08$ & 2.449 & 50.4 & $18.6 \pm 0.4$ \\
\hline 31 & $\begin{array}{l}\text { Cuba Gulch } \\
\text { (Rhyolite dike) }\end{array}$ & $\mathrm{RC}-5-2 \mathrm{~A}$ & Sanidine & $0.12,0.14$ & $15.62,15.60$ & 3.865 & 79.3 & $17.11 \pm 0.3$ \\
\hline
\end{tabular}

